Türk Kültürü İncelemeleri Dergisi 28, İstanbul 2013, 11-50.

\title{
İstanbul'un Yapı Sanatkârları: NAKKAŞLAR VE SIVACILAR (1700-1838)
}

Murat ULUSKAN"

\begin{abstract}
ÖZET
İstanbul'da, Osmanlı Sarayının "ehl-i hiref" denilen sanatkârları arasında özel bir yere sahip olan Hassa nakkaşlar ve dükkân sahibi nakkaş esnafi dışında sayılar çok daha kalabalık bir nakkas grubu daha vardı. Bunlar, amele sinıfi içerisinde yer alıp şehirdeki mirî, dinî ve sivil yapuların siva üstï boyalı nakışların gerçekleştirirlerdi. Ehl-i hiref çatısı altında yer aldıklarından dolayı Enderun Hazinedarbaşısına tâbi olan bu nakkaşların ustalık, kalfalık ve çıraklık nizamlarıla birlikte çalışma nizamlar da mevcuttu. Aym şekilde Sivacılar da yapı sektöründe faaliyet gösteren amele sinıfinın sanatkâr bir topluluğuүdu. Вu mesleği icra edenler çoğunlukla gayrimüslim sıvacılardı. Müslïman sivacıların sayısı daha az olup geneli askerî zümrelere mensuptu. 1776 tarihli Sivacı esnafi nizam ile müslim ve gayrimüslim swacıları yapılarda birlikte çalışmaları yasaklanmıştı. Nakkaş ve sivacılar, sanatların tekellerine almıs esnaflard ve birbirlerinin işlerine müdahale etmezlerdi. 1826 yılında Yeniçeri Ocă̆ının kaldıılması, ocağa bağh esnaf gruplarını etkisiz hale getirdi. Bundan istifade ile devlet, 1827 yllinda nakkas ve sivact esnafinin meslekî tekellerini tamamen ortadan kaldırdı. Bu çalışma, birbirini tamamlayıcı sanatlar icra eden ve sıkı ilişki içerisinde olan bu sanatkârların sarayla olan bağların, menşelerini, sayıların, ücretlerini ve 18. yüzyıldan itibaren örneklerine rastlanılan meslekî eğitim ve çalışma nizamların incelemektedir.

\section{Anahtar Kelimeler}

Nakkaş, sivacı, kalemkâr, sadekâr, meremmatcı, bostancı, İstanbul, yapı, inşaat, sanatkâr, süsleme, bezeme, tezyin.
\end{abstract}

\section{Giriş}

Sarayın dolayısıyla Padişah ve çevresinin himayesindeki sanatkârların çalışmalarıyla biçimlenen Osmanlı sanatının geniş coğrafi bölgelere yayılmasını sağlayan alanlar, uygulamalı sanatlar ve süsleme sanatlarıdır. Süsleme, bezeme ya da Osmanlıların kullandığı tabirle tezyîn, en genel anlamıla bir biçimin yüzeyinde düz ya da kabartma, boyalı ya da boyasız bir

\footnotetext{
* Dr., Marmara Üniversitesi Fen-Edebiyat Fakültesi Tarih Bölümü. muluskan@marmara.edu.tr
} 
takım motiflerle oluşturulan düzenlemelerdir. ${ }^{1}$ Resim sanatının bir kolu olan süslemenin ana teması desen, deseni oluşturan ise motiflerdir. ${ }^{2}$ Osmanlı süsleme sanatının tasarımcıları olarak bu sanatın motif, kompozisyon ve üsluplarını yaratan nakkaşlar, tarihte daha çok "ressam, minyatür ressamı" manasında kullanılan bir unvana sahip olmalarına rağmen bu unvanın çatısı altında yerine getirdikleri görevler çeşitlilik gösterir. Çadır, hall, kumaş gibi dokumaların, çini, ahşap, maden işleri ve mücevher gibi diğer sanatkârlar tarafından üretilen eserlerin desenlerini hazırlamak; ahşap ve mukavvadan yapılan küçük sandıkları bezemek; kitap sanatı kapsamında yazma eserlerin bezenmesi (müzehhiplik), resimlenmesi (musavvirlik), sayfalara cetvellerin çekilmesi (cetvelkeşlik) ve boyaların hazırlanması (renkzenlik) gibi işlerin yanı sıra saray yapılarının, köşklerin ve diğer binaların kalemişi gibi mimarî süslemelerini tasarlamak ve uygulamak da nakkaşların görevleri arasındadır. ${ }^{3}$

Hükümdar sarayı bünyesinde nakkaşhane bulunması geleneği, Selçuklulardan Osmanlılara geçen bir uygulamadır. Bu nakkaşhaneler, 14. yüzyıldan itibaren İran ve Hindistan'da kurulan Müslüman devletlerde hükümdarların desteğiyle faaliyet gösteren ve aynı zamanda sanatçıların eğitildiği kutub-hâne (kitab-hâne) denilen atölyelerin işlevini üstlenmiştir. ${ }^{4}$ Imparatorluğun farklı yerlerinden gelerek Saray nakkaşhanesinde çalışan ve ustaçırak usulüyle kendilerini geliştirerek sanatlarında yetkinleşen nakkaşlar, ortaya koydukları eserlerle Osmanlı süsleme sanatına farklı üsluplar kazandırmışlardır. Erken dönemlerde Selçuklu tesiriyle Rumî ve Hataŷ̀ üslupları etkindir. Fatih döneminde Baba Nakkaş üslubu, Kanunî döneminde meşhur nakkaş Şahkulu tarafından geliştirilip yaygın olarak kullanılan $S a z$ üslubu, ardından Şahkulu'nun öğrencisi Kara Memi tarafından oluşturulan Çiçek üslubu klasik Osmanlı sanatının motif, renk ve desenlerini belirlemiştir. ${ }^{5}$ 18. yüzyıl başlarında artmaya başlayan Batı tesiri altında, geleneksel

'Ayla Ödekan, “Bezeme”, Eczacıbaşı Sanat Ansiklopedisi, İstanbul 1997, I, s. 236.

2 Azade Akar-Cahide Keskiner, Türk Süsleme Sanatlarnda Desen ve Motif, İstanbul 1978, s. 10.

${ }^{3}$ Filiz Yenişehirlioğlu, "Klasik Dönem Osmanlı Sanatı”, Türkler, Ankara 2002, XI, 835; Banu Mahir, Osmanl Minyatür Sanatı, İstanbul 2005, s. 18; Nebi Bozkurt, "Nakkaş", Türkiye Diyanet Vakfı İslâm Ansiklopedisi (TDVİA), İstanbul 2006, XXXII, s. 326.

${ }^{4}$ B. Mahir, a.g.e., s. 17.

${ }^{5}$ F. Yenişehirlioğlu, a.g.m, s. 836-837. 
anlayışı kaybetmeden yeniliklere açık tutumuyla kendi üslubunu ortaya koyan Levnî de dönemin en önemli nakkaşlarından biridir. ${ }^{6}$

Osmanlı sanatında görülen bu üslup ve tesirler sadece kitap sanatlarında değil mimarî süsleme programlarında da yoğun bir şekilde hissedilmiştir. Özellikle kalemişi nakışların bu süslemelerde özel bir yeri vardır. Sarayın her çeşit nakış işlerini yapan nakkaşlar, saray içi ve dışındaki yapıların kalemişi desenlerinin hazırlanması ve uygulanmasında bizzat yer alarak üsluplarını sergilemişlerdir. Dinî ve sivil mimariyi oluşturan binaların iç duvarlarını, kubbelerini ve tavanlarını sıva, ahşap, taş, bez ve deri gibi malzemeler üzerine renkli boyalar ve bazen de altın varak kullanılarak, kalem tabir edilen ince kıllı fırçalarla yapılan nakışlara kalemkâri ya da $k a$ lemişi, bu sanatı uygulayanlara da kalemkâr denmiştir.

Mimaride iç mekân süsleme elemanı olarak kullanılan ve kalemişi bezeme de denilen boyalı nakışların 14. yüzyıldan itibaren yaygın olarak uygulandığı alan sıva üzerinedir. ${ }^{8}$ Sıva üstü kalemişleri dış etkenlerden iyi bir şekilde korunur ve kullanılan malzeme kaliteli olursa yüzyıllarca dayanması mümkündür.' Osmanlı yapılarında, insan elinin uzanamadığı yükseklikteki bütün iç yüzeylerin süslenmesinde kalemişleri tercih edilmiştir. ${ }^{10}$ Çok

\footnotetext{
${ }^{6}$ B. Mahir, a.g.e., 1 s. $69-170$.

7 Celâl Esad Arseven, "Kalemkâri”, Sanat Ansiklopedisi, İstanbul 1983, III, s. 916; Ayla Ödekan, "Kalemkâri”, Eczacıbaşı Sanat Ansiklopedisi, İstanbul 1997, II, s. 933-934.

${ }^{8}$ Selçuklu iç mimarî süslemesinde bitkisel ve geometrik şekilli boyamaların varlığ hakkında bkz. Gönül Öney, Anadolu Selçuklu Mimarisinde Süsleme ve El Sanatlar, Ankara 1978, s. 75. Ayrıca 14. yüzyıl erken Osmanlı mimarisinde kullanılan süsleme türleri için bkz. Yıldız Demiriz, Osmanlı Mimarisinde Süsleme I Erken Devir (1300-1453), İstanbul 1979, s. 11-26.

9 "Sıva Üstü Kalemişleri: Klasik mimari eserlerimizin hemen hepsinde tatbik edilen bir tekniktir. Bu teknikte kalem işinin uygulanacağı zemine önce kireç badanası yapılır. Daha sonra nakışların yapılacağı zeminler ölçümlenip taksimatlanır. Önceden ölçülerine göre kâğıtlar üzerine hazırlanmış desenler iğne ile delinerek kalıp haline getirilir ve özel bir kömür tozu ile zemine geçirilir. Zemindeki desenleri çalışma sisteminde, sırası ile önce desenlerin zeminleri belirli fırçalar ile kestirilir ve zeminlerin içleri doldurulur. Diğer renkler de konulduktan sonra en son olarak kontürler (tahrir) çekilir kalemişi tamamlanır" (M. Semih İrteş, "Kalem İşlerimizin Bugünü ve Yarını", Türkiye'de Sanatın Bugünü ve Yarmı, Tebliğler, Hacettepe Ün. Güzel Sanatlar Fak. I. Ulusal Sanat Sempozyumu 17-19 Nisan 1985, Ankara 1985, s. 425-426).

${ }^{10}$ Celâl Esad Arseven, Türk Sanatı Tarihi, Menşeinden Bugüne Kadar Mimarî, Heykel, Resim, Süsleme ve Tezyinî Sanatlar, İstanbul Tarihsiz, s. 726; Yıldız Demiriz, "Osmanlı Kalem İşleri”, Osmanl, Ankara 1999, XI, s. 297.
} 
geniş bir motif dağarcığına sahip olan Osmanlı nakkaşlarının yapılarda uyguladıkları kalemişlerindeki hâkim beğeniyi ise çiçek, yaprak, ağaç, yemiş ve meyvelerle stilize edilen bitkisel motifler oluşturmuştur. ${ }^{11}$

18. yüzyılda Batı ile artan siyasî ve kültürel ilişkiler Türk süsleme sanatını da etkilemiştir. İlk Batı tesirleri Sultan III. Ahmed döneminde (1703-1730) başlamış ve bu geçiş dönemini Ahmed Refik, o dönem kültürünün bir sembolü olan lâle çiçeğinden dolayı Lâle Deori olarak adlandırmıştır. 1740'lı yıllardan itibaren ise Batının barok ve rokoko tarzları Türk sanatında, özellikle de iç mimarî süslemede etkisini göstermiş, Osmanlı nakkaşları bu tesirlere kendi zevk ve görüşlerini de katarak Türk Baroğu ya da Türk Rokokosu olarak adlandırılan yeni bir üslup oluşturmuşlardır. ${ }^{12} \mathrm{Bu}$ süreçte, yüzyıllardır Osmanlı yapılarının duvarlarını süsleyen bitkisel motifli boyalı nakışların yerini barok ve rokoko çerçevelerinin içerisine yerleştirilmiş manzara kompozisyonları almış, geleneksel bir sanat dalı olan kalemişi duvar nakkaşlığı da duvar ressamlığına dönüşmeye başlamıştır. ${ }^{13}$

Geç dönem Osmanlı sanatında 18. yüzyılın son çeyreğinde ortaya ç1kan duvar resmi 19. yüzyıl sonlarına kadar gelişimini sürdürmüştür. Duvar resimleri başlıca, tek yapı (cami, konak) tasvirleri, gemi tasvirleri, meyve ve çiçek tasvirleri, nadir de olsa insan ve hayvan figürleri ile genel manzara tasvirleri gibi konuları içerir. Bunlar arasında en çok işlenen manzara tasviridir. Sultan I. Abdülhamid döneminde (1774-1789) görülen manzara tasvirleri III. Selim devrinde (1789-1807) giderek çoğalmıştır. Bu resimlerde minyatür sanatının özellikleri korunarak Batı resminin derinlik kavramı uygulanmaya çalışılmıştır. Yapılar geleneksel kalemişi tekniğinde, kuru sıva ya da ahşap üzerine su veya tutkal ile karıştırılmış toprak boyalarla

${ }^{11}$ Serpil Bağcı, “Osmanlı Mimarisinde Boyalı Nakışlar”, Osmanlı Uygarlı̆̆ı, haz. Halil İnalc1k-Günsel Renda, Ankara 2002, II, s. 738-744. Osmanlı mimarî süslemesinde kullanılan motif ve kompozisyonlar hakkında bkz. Aziz Doğanay, "Osmanlı Mimarisinde Tezyînât”, Osmanl, Ankara 1999, XI (Kültür ve Sanat), s. 324-329.

${ }^{12}$ Semavi Eyice, "XVIII. Yüzyılda Türk Sanatı ve Türk Mimarisinde Avrupa NeoKlasik Üslubu", Sanat Tarihi Yıllı̆̆ kizinci Yüzynl İstanbul Mimarisinde Batılılaşma Süreci, İstanbul 1975, s. 10-11; A. AkarC. Keskiner, a.g.e., s. 21.

${ }^{13}$ Günsel Renda, Batılılaşma Döneminde Türk Resim Sanatı 1700-1850, Ankara 1977, s. 78; G. Renda, "Resim ve Heykel”, Osmanlı Uygarlı̆̆ı, haz. H. İnalcık-G. Renda, Ankara 2002, II, s. 935. 
işlenmiştir. Sultan II. Mahmud döneminden (1808-1839) itibaren ise manzara kompozisyonları anıtsal boyutlara ulaşmıştır. Bu süreçte, Batı etkisinin giderek arttığ yerini yağlıboya almaya başlamıştır. ${ }^{14}$

Osmanlı mimarî süslemesinde boyalı nakışların geçirdiği bu değişim, doğrudan sanat tarihiyle alakalı yanları olmakla birlikte şehirlerin sosyal ve ekonomik tarihleriyle de yakından ilgilidir. Yapı tipleri insanların barınma, eğitim, savunma, ticaret ve ibadet gibi işlemleri hakkında bilgi verirken; yapı malzemesi, süslemesi ve işçilik de toplumun sosyal ve ekonomik düzeyini belirlemektedir. 14. ve 19. yüzyıl Osmanlı yapılarının nitelik ve nicelik bakımından aynı olmayışı, aradan geçen zaman içerisinde meydana gelen sosyal, kültürel ve ekonomik farklılaşmadandır. Bu değişiklikler mimariye yansıdığı gibi süsleme sanatlarında dönemlere özgü üslup farklılıklarını da beraberinde getirmiştir. ${ }^{15}$

Osmanlı İmparatorluğu'nda yapılarda kullanılan işgücü, vasıflı ve vasıfsız amelelerden oluşan ve gündelikle çalışan serbest statüde işçilerdi. Taşçı, duvarcı, dülger, demirci, kurşuncu, camcı, nakkaş, sıvacı, lağımcı ve kaldırımcı gibi vasıflı usta, kalfa ve çırakların yanında ırgad ve hamal gibi vasıfsız olanlar da amele sınıfına mensuptu. Şehirde serbest bir şekilde çalışan bu işçilerin birtakım mecburi hizmet mükellefiyetleri vardı. Devlet binaları, Padişah ya da hanedan mensupları tarafından yaptırılan cami, imaret, medrese, kütüphane gibi yapıların inşa ve tamiratlarında ücret mukabili zorunlu istihdam edilirlerdi. Ayrıca içlerinden bir kısmı, sefer esnasında ordunun çeşitli ihtiyaçlarını karşılamak üzere, "orducu” namıla muhtelif esnaf gruplarıyla birlikte sefere iştirak etmek zorundayd $1 .{ }^{16}$ Esnafın örgütlenme aşamasında nizamlarını belirlemeleri ve bu nizamları kendilerini bağlayıcı şekilde resmî hale getirmeleri esnaf-devlet ilişkilerini kolaylaştırmıştı. Bu nizamlarda ustalık, kalfalık gibi meslekî unvanların

${ }^{14}$ Geniş bilgi için bkz. Rüçhan Arık, “Osmanlı Sanatında Duvar Resimleri”, Osmanlı, Ankara 1999, XI, s. 423-436.

${ }^{15}$ F. Yenişehirlioğlu, a.g.m, s. 827-828.

${ }^{16}$ Ömer Barkan, "XVI.-XVIII. Asırlarda Türkiye'de İnşâat İşçilerinin Hukukî Durumu”, Sosyal Siyaset Konferanslar, Ondördüncü Kitap, İstanbul 1963, s. 22-23, 31-36. 1553-1558 yılları arasında Süleymaniye Camii ve İmareti inşaatında çalışan nakkaşların sayısı 63 kişiydi (Ömer Lûtfi Barkan, "Türk Yapı ve Yapı Malzemesi Tarihi İçin kaynaklar”, İktisat Fakültesi Mecmuası, İstanbul 1956, XVII, 14). 
kazanılma şartları, çıraklık ve kalfalık süreleri, çalışma şartları, üretilecek malın cinsi ve kalitesi, hammaddenin temin ve tevzii gibi konular yer alırd1. Esnaf içerisinde çoğunluğun iradesi belirli bir konuda değişirse, bu değişiklik Kadı'nın kontrolü ve Divân'ın onayıyla nizama eklenir veya yeni bir belge düzenlenirdi. ${ }^{17}$

Osmanlı sanatı ve mimarisiyle ilgili yapılan çalışmaların geneli, günümüze ulaşan eserlerin mimarî ve sanatsal özelliklerinin incelenmesine yönelik araştırmalardır. Yapı sektöründe faaliyet gösteren esnaf örgütleri ile bu eserlerin meydana getirilmesinde rol alan yapı sanatkârları hakkında yapılan çalışmalar ise oldukça sınırlıdır. Özellikle de sanatkârların yetişmeleri, çalışma usulleri, halk ve devletle olan münasebetlerine dair bilgiler tatminkâr olmaktan uzaktır. Araştırma konumuz olan nakkaş ve sıvacılar, amele sınıfının iki sanatkâr topluluğu olarak meslekî eğitim ve çalışma nizamlarını kayıt altına aldırarak örgütlenmelerini gerçekleştirmiş esnaflardır. Çalışmamızda, nakkaşlık unvanı altında icra edilen sanatların çeşitliliği, önemi ve sanatkârların saraya olan bağlılıkları dolayısıyla öncelikle nakkaşlar, sonrasında ise sıvacılar incelenmektedir. Amacımız, Osmanlı yapı sektöründe birbirini tamamlayıcı sanatlar icra eden ve sıkı ilişki içerisinde oldukları anlaşılan bu sanatkârları, arşiv kayıtlarından elde edilen bilgiler çerçevesinde tanıtarak bu alanda yapılacak araştırmalara katkıda bulunabilmektir.

$\mathrm{Nakk}$ a ş l a r

Klasik dönem Osmanlı sanatının doğuşunu ve gelişimini hazırlayan nakkaşlar, Osmanlı Sarayının "ehl-i hiref” denilen sanatkârları arasında özel bir yere sahipti. Ehl-i hiref, Padişah ve çevresinin himayesindeki sanatç1 ve zanaatçı bölükleriyle Osmanlı Sarayının pek çok sanatsal gereksinimini karşılayan bir örgüttü. Sarayın "bîrûn" denilen dış hizmet birimleri arasında yer alan bu sanatkârlar, Enderun ağalarından Hazinedarbaşının emrinde olup maaşlarını da onun aracılığıyla alırlardı. ${ }^{18}$ Sayıları yaptıkları

\footnotetext{
${ }^{17}$ Mehmet Genç, “Osmanlı Esnafı ve Devlet”, Osmanlı Imparatorluğu'nda Devlet ve Ekonomi, İstanbul 2000, s. 296.

${ }^{18}$ Filiz Çağman, “Mimar Sinan Döneminde Saray'ın Ehl-i Hiref Teşkilâtı”, Mimar Sinan Dönemi Türk Mimarlığı ve Sanatı, İstanbul 1998, s. 74; F. Çağman, "Ehl-i Hiref”, Dünden Bugüne İstanbul Ansiklopedisi, İstanbul 1994, III, s. 145.
} 
işlere ve ihtiyaca göre değişirdi. Teşkilâtlarına dair en önemli bilgiler ise ehl-i hiref mevâcib (maaş) defterlerinde bulunurdu. Arşiv kayıtlarında 16. yüzyıl başlarından 18. yüzyıl sonlarına kadar örneklerine rastladığımız bu defterlerde, sanatkârların ve yetişmekte olan öğrencilerinin bölükler halinde isimleri, menşeleri, kıdemlerine göre yevmiye üzerinden ödenen üç aylık maaşları, terfi, terakki ve ölüm kayıtları belirtilirdi. ${ }^{1}$

Bursa ve Amasya'da oluşup Edirne Sarayında gelişmeye başlayan Osmanlı nakkaşlı̆̆ında, İstanbul'un fethi önemli bir dönüm noktasıydı. Fatih'in sanata ve sanatçılara verdiği destek kapsamında nakkaşlar için Saray bünyesinde bir nakkaşhane tesisi, portre ve madalyonlarını yaptırmak için İtalya'dan sanatçılar davet etmesi, ${ }^{20}$ Otlukbeli Savaşından (1473) sonra İran ve Azerbaycan'dan bazı ilim ve sanat erbabını getirtmesi Türk nakış sana$\operatorname{tın}^{21}{ }^{21}$ 16. yüzyılda ulaştığı zirvenin başlangıcını oluşturdu. Sultan II. Bayezid devrinde (1481-1512) sanat ve sanatçıyı himaye Fatih dönemiyle kıyaslanamayacak derecede arttı. Hükümdarlığı öncesi 27 yıl valilik yaptığı Amasya'daki kültürel zenginlik ve üretilen eserlerin yoğunluğu tahta çıkt1ğında da sürdü. ${ }^{22} 1478$ yılında Saraydaki ehl-i hiref mevcudu 12 kişi iken 1503'de 146'ya yükseldi. 1503-1512 yıllarına ait kayıtlara göre bu rakam içerisinde nakkaşların sayısı $21 \mathrm{idi}^{23}$

${ }^{19} \mathrm{Bu}$ defterlerin tanıtımı ve 1526 tarihli defterde yer alan sanatkâr listeleri için bkz. İsmail Hakkı Uzunçarşılı, “Osmanlı Sarayı'nda Ehl-i Hıref (Sanatkârlar) Defterleri”, Belgeler, XI/15 (1986), s. 23-76.

${ }^{20}$ Nurullah Berk, "Fatih Sultan Mehmet ve Venedikli Ressam Gentile Bellini”, Ankara Üniversitesi İlâhiyat Fakültesi Dergisi, II/2, Ankara 1953, s. 143-160.

${ }^{21}$ Türk nakış tarihi ile ilgili öncü çalışmalar Fuat Köprülü, Süheyl Ünver ve Rıfkı Melûl Meric tarafından yapılmıştır. Köprülü, 1921 yılında İkdam gazetesinde konuyla ilgili beş makale yazmıştır. Bu makaleler için bkz. Halil Buttanrı, "Fuat Köprülü'nün "Osmanlılarda Nakış Târihine Dâir” Beş Makalesi”, Osmangazi Üniversitesi Sosyal Bilimler Dergisi, 2 (2001), s. 17-46. Süheyl Ünver, Selçuklularda ve Osmanlllarda Resim, Tezhip ve Minyatür, İstanbul 1943 ve Fatih Devri Saray Nakışhânesi ve Baba Nakkaş Çalışmaları, İstanbul 1958 gibi kitap ve pek çok makalesiyle konuya dikkat çekmiştir. Rıfkı Melûl Meriç'in 1953 yılında Osmanlı arşiv belgelerine dayalı yaptığı çalışması ise günümüzde hâlâ bir başvuru eseri olma konumunu muhafaza etmektedir (Rıfkı Melûl Meriç, Türk Nakış San 'atı Tarihi Araştırmalarn 1 Vesikalar, Ankara 1953).

${ }^{22}$ Zeren Tanınd1, Türk Minyatür Sanatı, İstanbul 1996, s. 12-13.

${ }^{23}$ Hilal Kazan, "Osmanlı Sarayının Sanatı Himayesinin Mâlî Boyutları (XVI. Asrın İlk Çeyreğinde II. Bayezid'in İn ‘âmât Defteri Çerçevesinde)”, İ̈̈EF Tarih Dergisi, Sayı 47, İstanbul 2009, s. 108-111. 
İmparatorluğun güçlenmesine paralel olarak saray sanatkârlarının mevcudu da arttı. Yavuz Sultan Selim 1514 Çaldıran Zaferi sonrasında Safevîlerden Tebriz'i aldığında, Tebriz Nakkaşhanesini dönemin en meşhur sanatçı ve sanat eserleriyle dolu buldu. Aralarında Horasanlı sanatçıların da bulunduğu bir grup Tebrizli sanatçıyı önce Amasya'ya ardından da Sarayda istihdam edilmek üzere İstanbul'a gönderdi. ${ }^{24}$ Bunların toplamı 38 kişi olup 16'sı nakkaş, 18'i "müteferrikan" başlığı altında farklı dallardan sanatkârlar ve 4'ü de sâzendegân idi. Ayrıca yanlarında 23 kişiden ibaret oğulları olup onlar da sanatlarında ustayd $1 .{ }^{25}$ Tebriz'den gelenlerle birlikte ikiye katlanan nakkaş sayısı, Kanunî dönemine ait 1526 tarihli ehl-i hiref defterine göre 29 usta ve 12 de çırak olmak üzere 4l'e ulaşmışt1. ${ }^{26}$

Ehl-i hiref defterlerinde "Cemâ'at-i Nakkāşân-1 Hâssa" başlı̆̆1 altında yer alan nakkaşların, 1545 yılına ait kayıtlarda Bölük-i Rûmiyân ve Bölük-i Acemân adlarıyla iki bölüğe ayrılmış oldukları görülür. Bölük-i R̂̂miyân, 24'ü usta 20'si çırak olmak üzere 44 kişiden oluşan Anadolu ve Rumeli kökenli nakkaşlardı. Bölük-i Acemân ise 11'i usta 4'ü çırak toplam 15 nakkaşla Tebrizlilerden müteşekkildi. ${ }^{27}$ Nakkaşlardaki bu iki ayrı bölük uygulamasına sayının 1558 'de $35^{\prime} \mathrm{e}^{28}, 1564$ 'de $32^{\prime}$ ye $^{29}$ düşmesi ve Tebrizlilerin mevcudunun da giderek azalması üzerine Kanunî dönemi sonrasında son verildiği 1596 yılına ait maaş listesinden anlaşılmaktadır. ${ }^{30}$

\footnotetext{
${ }^{24}$ Z. Tanind1, a.g.e., s. 18-19.

${ }^{25}$ Tebriz'den gelen ustaların isim listesi için bkz. Topkapı Sarayı Müzesi Arşivi Defterleri (TSMA.d), nr. 9784. Bu liste Uzunçarşılı'nın makalesinde yer almakla birlikte kaynağı belirtilmemiştir (a.g.m, s. 24).

${ }^{26}$ TSMA.d, nr. 9706-1, vr. 3b-4b (Ocak 1526). Uzunçarş11, bu defterin numarasını 93062 (a.g.m, s. 25), Rıfkı Melûl Meriç ise 9613-1 (a.g.e., 3) olarak vermektedir.

${ }^{27}$ TSMA.d, nr. 9706-4, vr. 2b-3b (Mart-Mayıs 1545). Meriç, defter numarasını 9613-3 olarak vermektedir (a.g.e., s. 5). Tamamı yayımlanan 1545 tarihli ehl-i hiref defteri için bkz. Bahattin Yaman, "1545 Yılı Osmanlı Saray Sanatkârları”, Belleten, Sayı 264 (Ağustos 2008), s. 501-534.

${ }^{28}$ TSMA.d, nr. 9612, vr. 2a-2b (1558).

${ }^{29} 1564$ yılında yapılan sayımda, hayatta olan 32 nakkaş arasında Tebrizlilerin sayısının 7, o tarihe kadar ölen nakkaş mevcudunun ise 56 olduğu görülmektedir (TSMA.d, nr. 808, vr. 4a-4b, Mayıs-Haziran 1564).

${ }^{30}$ TSMA.d, nr. 9613-1, vr. 2b-3b, Mart-May1s 1596.
} 
16. yüzyıl sonlarında kapıkulu sayısında yaşanan artış ehl-i hirefi de etkiledi. 1596-1601 yılları arasında, nakkaş sayısı otuz yıl öncesine göre dört kat artarak 66'sı usta 58'i çırak olmak üzere 124'e yükseldi. ${ }^{31}$ Ehl-i hiref kadrolarındaki bu anormal şişkinlik, Sultan I. Ahmed dönemi (1603-1617) başlarında giderildi ve nakkaşların sayısı yarıdan fazla azaltılarak 50'lere kadar düşürüldü. ${ }^{32}$ IV. Murad devrinde (1623-1640) 40'lı rakamlara inen nakkaşlar, ${ }^{33}$ bu sayılarını 1680 'li yıllara kadar muhafaza ettiler. ${ }^{34} 1683$ 'deki başarısız Viyana kuşatması sonrası devam eden uzun savaş döneminde ise mevcutları 10'un altına düşürüldü. ${ }^{35}$ Çıraklık kadrolarının da artık yer almadığ listelerdeki nakkaş sayısı 18 . yüzyıl boyunca 7-8 kişiyi aşmadı. ${ }^{36}$

Hassa nakkaşlar cemaatinin başında Ser-nakkāşân unvanıyla bir Nakkaşbaşı bulunurdu. Ehl-i hiref defterlerinde 1630'lu yıllara kadar Ser-bölük olarak da geçen Nakkaşbaş1, ${ }^{37}$ bu tarihlerden itibaren sadece Ser-nakkāşân olarak yer almaya başladı. 16. yüzyıl sonlarında, artan nakkaş mevcuduyla birlikte cemaat içerisinde Nakkaşbaşıya yardımcı yeni idarî görevler de oluşturuldu. Bunlar Kethüda, Ser-bölük, Ser-oda-i evvel ve Ser-oda-i sânî idi. O döneme kadar tek bir Bölükbaşı vardı o da Nakkaşbaşıydı. Kethüdalık uygulamasıyla beraber bir Bölükbaşılık daha ihdas edildi ve her iki görevli 17. yüzyıl ortalarına kadar Nakkaşbaşıdan sonra gelen en kıdemli nakkaşlar

${ }^{31}$ TSMA.d, nr. 9613-1, vr. 2b-3b, Mart-Mayıs 1596; Başbakanlık Osmanlı Arşivi (BOA), Maliyeden Müdevver Defterler Tasnifi $(M A D . d)$, nr. 7257, s. 5-6, Ağustos-Kasım 1596; MAD.d, nr. 7442, s. 4-6, Temmuz-Ekim 1599; TSMA.d, nr. 2924, vr. 2b-3b, Temmuz-Eylül 1601.

${ }^{32}$ TSMA.d, nr. 7253, vr. 2b-3a, Mayı-Ağustos 1605; nr. 9613-3, vr. 2b-3a, Ağustos-Ekim 1606; BOA, MAD.d, nr. 4586, Ocak-Nisan 1608.

${ }^{33}$ TSMA.d, nr. 2993, vr. 2b, Temmuz-Ekim 1624; BOA, MAD.d, nr. 7444, s. 6-7, MartHaziran 1626; TSMA.d, nr. 9613-4, vr. 2b-3a, Şubat-May1s 1638.

${ }^{34}$ TSMA.d, nr. 3410, vr. 3b-4a, Ocak-Nisan 1650; nr. 9613-8, vr. 3b-4a, Mart-Haziran 1655; BOA, $M A D . d$, nr. 7250, s. 6-7, Şubat-Mayıs 1663; TSMA.d, nr. 9604-2, vr. 2b-3a, Ocak-Nisan 1681.

351688 yılına ait ehl-i hiref defterinde nakkaş sayısının 9 olduğu görülmektedir (TSMA.d, nr. 9613-12, Mayıs-Temmuz 1688). Benzer bir uygulama Hassa mimarlar ocağında da yapılmış, 1691 yılında yapılan bir teftiş sonucunda görevini aksatan 23 kişi ocaktan çıkartılarak sayıları 11'e düşürülmüştü (Fatma Afyoncu, XVII. Yüzyılda Hassa Mimarlar Ocă̆ı, Ankara 2001, s. 28).

${ }^{36}$ 18. yüzyıla ait nakkaş listeleri için bkz. R. M. Meriç, a.g.e., 34-47.

${ }^{37}$ TSMA.d, nr. 9706-4, vr. 2b, Mart-May1s 1545; nr. 808, vr. 4a, May1s-Haziran 1564; nr. 7253, vr. 2b, Mayıs-Ağustos 1605; BOA, MAD.d, nr. 7444, s. 6, Mart-Haziran 1626. 
olarak maaş listelerinde yerlerini aldılar. ${ }^{38}$ Onlardan sonra gelenler ise $\mathrm{Bi}$ rinci ve İkinci Odabaşılardı. Nakkaşhanedeki odalarda çalışan nakkaşların başında bulundukları anlaşılan bu görevlilerin vazifesi, Sultan I. Ahmed döneminde nakkaş sayısının düşürülmesiyle birlikte "Ser-oda" denilen tek bir Odabaşının sorumluluğuna terkedildi. ${ }^{39}$ Uzun süre devam eden Odabaş1lık sistemine 1640 'lı yıllarda son verildi. ${ }^{40}$ Yüzyılın sonlarına doğru ise önce Kethüdalık ardından da Bölükbaşılık uygulaması kaldırıldı ${ }^{41}$ ve Nakkaşbaşı, mevcutları 7-8 kişiye inen nakkaşların başında tek yetkili amir olarak 18. yüzyıl boyunca görevini sürdürdü.

Ehl-i hirefe tâbi Hassa nakkaşların âmiri Nakkaşbaşı olmakla birlikte tayin, terfi ve maaş işlemleri diğer sanatkâr bölüklerinde olduğu gibi Enderun-1 hassa Hazinedarbaşısı tarafından gerçekleştirilirdi. Nakkaşlığa yeni tayin olunanlara "ibtidâ tezkiresi" denilen, kadroya atandığına ve ilk maaşına dair bir belge çıkartılırdı. ${ }^{42}$ İçlerinden biri öldüğünde, boşalan gediği (kadrosu) ve terakkilerden arındırılmış çıplak maaşı yeni tayin edilecek olana, terakkileri ise içlerinde "hak edene/edenlere" yine maaş zammı olarak verilirdi. ${ }^{43}$ Tüm bu işlemler Enderun Hazinedarbaşısının arzuhali üzerine Sadrazamin buyruldusuyla resmîleşirdi.

Ehl-i hiref mensupları, sanatlarıyla alakalı el işlerini ve uzun süre üzerinde çalıştıkları eserleri bayramlarda Padişaha hediye olarak takdim eder,

${ }^{38}$ BOA, MAD.d, nr. 7257, s. 5, Ağustos-Kasım 1596; nr. 3697, s. 4, Ekim-Aralık 1607; nr. 7443, s. 4, Ağustos-Kasım 1621; TSMA.d, nr. 486, vr. 2b, Ocak-Mart 1651; MAD.d, nr. 7250, s. 6, Şubat-Mayıs 1663.

${ }^{39}$ TSMA.d, nr. 9613-1, vr. 3a, Mart-Mayıs 1596; nr. 2924, vr. 2b, Temmuz-Eylül 1601; nr. 7253, vr. 2b, Mayıs-Ağustos 1605.

${ }^{40}$ BOA, MAD.d, nr. 7443, s. 4, Ağustos-Kasım 1621; TSMA.d, nr. 9613-4, vr. 2b, ŞubatMayıs 1638; nr. 3410, vr. 3b, Ocak-Nisan 1650.

${ }^{41}$ BOA, MAD.d, nr. 7250, s. 6, Şubat-Mayıs 1663; TSMA.d, nr. 9604-2, vr. 2b, OcakNisan 1681; nr. 9613-12, vr. 2a, May1s-Temmuz 1688.

${ }^{42}$ İbtidâ tezkiresini kaybeden bir nakkaşa belgesinin yeniden verilmesine dair Enderun Hazinedarbaşısının arzı için bkz. BOA, İbnülemin Tasnifi Saray Evrakı (IE.SM), nr. 3147, 9 Mart 1712.

${ }^{43}$ Örnekler için bkz. BOA, İE.SM, nr. 1373, 24 Haziran 1671; BOA, Cevdet Tasnifi Saray Evrakı (C.SM), nr. 1526, 19 Şubat 1717; BOA, Ali Emirî Tasnifi Sultan III. Mustafa Evrakı (AE.SMST.III), nr. 13495, 8 Eylül 1772; BOA, Cevdet Tasnifi Belediye Evrakı (C.BLD), nr. 1908, 1 Aralık 1789; BOA, Cevdet Tasnifi İktisat Evrak1 (C.İKTS), nr. 1436, 23 Kasım 1800; C.SM, nr. 1647, 22 Temmuz 1811. 
karşılığında da mevkilerine ve eserlerinin değerine göre "in 'am" denilen para veya hil 'at (kaftan) ile ödüllendirilirlerdi. Sanatkârın adı, eserinin türü, karşılı̆̆ında ödenen paranın tutarı ve verilen kaftanın cinsi in 'am defterine kaydedilirdi. ${ }^{44}$ İşlerin yoğun olduğu zamanlarda ya da yapılacak işe uygun yetenekli kimse Ehl-i hiref içerisinde bulunamadığında, çarşı esnafı arasından ücreti karşılığında yeterli sayıda usta temin edilerek sarayda çaliştırılırdi. ${ }^{45}$

İstanbul'da Yeni Saray (Topkapı) bünyesinde yer alan Hassa nakkaşlardan ayrı olarak Eski Saraya tâbi başka bir nakkaş cemaati daha vardı. Sayıları hakkında henüz bir bilgiye ulaşamasak da maaşlarını İstanbul Harc-1 hassa malından aldıkları, tayinlerine yönelik arzın 18. yüzyıl başlarında Şehremini, sonlarında ise Eski Saray Ağası tarafından kaleme alındığı eldeki az sayıda belgeden öğrenilmektedir. ${ }^{46}$

Osmanlı Sarayında, yapılardaki bozulan yerlerin onarımında çalıştırılmak üzere meremmatcılar ${ }^{47}$ istihdam edilirdi. Uzmanlık alanlarına göre sinıflandırılan merammatcılar arasında nakkaş meremmatcılar da bulunurdu. Ehl-i hirefe tâbi olmayan bu nakkaşlar, Topkapı Sarayının birinci avlusunda inşaat malzemesi deposu olarak kullanılan Anbar-1 âmireye ${ }^{48}$ bağlı

${ }^{44}$ Kanunî Sultan Süleyman zamanında, nakkaşlarından Şahkulu'nun bir büyük nakışlı tabak ve bir kâğıt üzerine peri sureti, Büyük Hasan Çelebi'nin bir lacivert veli nakışlı âsâ ve bir münakkaş kırmızı el sandığı takdim ettikleri görülmektedir. Bu döneme ait üç hediye defteri ve karşılığında verilen in 'amlar için bkz. Uzunçarş1lı, "Ehl-i Hıref”, 65-76. Keza II. Bayezid devrinin en önemli nakkaşlarından Hasan'a, Şeyh Hamdullah'ın Sultan'a takdim ettiği iki Mushaf'ın tezhiplerini yaptığından dolayı beş bin akçe ile benekli kumaştan yapılmış iki adet kaftan in'am edilmişti (H. Kazan, a.g.m, s. 118-119).

${ }^{45}$ Z. Tanınd1, a.g.e., s. 16.

${ }^{46}$ Söz konusu iki ayrı tayin belgesi için bkz. BOA, Ali Emirî Tasnifi Sultan III. Ahmed Evrakı (AE.SAMD.III), nr. 8784, 23 Haziran 1713; C.SM, nr. 1241, 20 Haziran 1804.

${ }^{47}$ Merâmetci/Meremmetci: Bozuk şeyleri üstünkörü ve geçici olarak tamir eden kimse (Şemseddin Sami, Kâmûs-ı Türk̂, İstanbul 2010, s. 1319, 1328). Bu kelime, metin içerisinde belgelerde geçtiği şekliyle kullanılmıştır.

${ }^{48}$ Birinci avlunun solunda, Aya İrini Kilisesi'nin hemen arkasında dış bahçelere inen yokuşun yakınındaki Anbar-1 âmire, Şehreminin denetimi altındaydı. Sarayda kullanılan inşaat malzemelerinin yığıldığ 1 bölümler yanında, burada marangoz ve diğer ustaların sarayı süslemek ve bakımlı tutmak için çalıştığı işlikler de bulunuyordu. Geniş bilgi için bkz. Gülru Necipoğlu, 15. ve 16. Yüzyılda Topkapı Sarayı Mimarî, Tören ve İktidar, çev. Ruşen Sezer, İstanbul 2007, s. 75-76. 
ulufeli bir cemaatti. Kayıtları Harc-1 hassa Emini defterlerinde muhafaza edilir, tayinleri ise Nakkaşbaşının önerisi ve Harc-1 hassa Emininin arzuhali üzerine gerçekleşirdi. ${ }^{49}$ Nitekim Yavuz Sultan Selim'in Tebriz'den getirttiği ve içlerinde meşhur Şahkulu'nun da bulunduğu nakkaşlar da önce İstanbul Hassa harcına kaydedilmiş, daha sonra Kanunî döneminde ehl-i hirefe dâhil edilmişlerdi. ${ }^{50} \mathrm{Bu}$ bilgi, Saray nakkaşlarından bir kısmının Anbar-1 âmire bünyesinde istihdam edildiğini ve çalışma mekânlarının da burada olabileceğini göstermektedir.

Saray Nakkaşhanesi, Nakkaşbaşının gözetimindeki nakkaşların bir araya gelerek usta-çırak usulüyle çeşitli sanatları uygulamalı olarak tatbik ettikleri, toplu olarak eser verdikleri, bitmiş eserlerini teslim ettikleri, yeni görevlerini öğrendikleri bir çalışma ve toplanma mekânıydı. Filiz Çağman'ın yapmış olduğu araştırma neticesinde Hassa Nakkaşhanenin, Topkapı Sarayının dışında Ayasofya'nın karşısında yer alan Arslanhanenin yanında olduğu anlaşılmıştır. Ayrıca, Sarayın birinci avlusundaki Anbar-1 âmire bitişiğinde nakkaşlar için atölyeler tahsis edildiği ve Arslanhanenin üst katının da İstanbul'daki nakkaş esnafınca nakkaşhane olarak kullanıldığı bu çalışmayla aydınlatılmıştır.

${ }^{49}$ BOA, İbnülemin Tasnifi Tevcihat Evrakı (İE.TCT), nr. 627, 5 Ekim 1673. İstanbul, Galata, Gelibolu, Edirne ve Bursa gibi şehirlerde Harc-1 hassa eminleri vard1. Bu eminler sarayların ve saraylıların yiyecek ve giyecek giderlerini, aylıklarını, saray için çalışan bazı meslek sahiplerinin ücretlerini, emeklilerin emekli maaşlarını, giderleri Hazinece karşılanan cami ve mescitlerdeki görevlilerin maaşlarını öderdi (Halil Sahillioğlu, “Emin”, TDVİA, İstanbul 1995, XI, 112).

${ }^{50}$ TSMA.d, nr. 9706-1, vr. 3b-4b.

${ }^{51}$ Filiz Çağman, "Saray Nakkaşhânesinin Yeri Üzerine Düşünceler”, Sanat Tarihinde Doğudan Batıya, Ünsal Yücel Anısına Sempozyum Bildirileri, İstanbul 1989, s. 35-46. Saray nakkaşhanesinin dışında, Tersâne-i âmirede donanma-yı hümâyun gemilerinin boya ve nakış işlerinin yapılmasından sorumlu bir Tersane-i âmire Nakkaşbaşısı ve Tersane Nakkaşhanesi bulunuyordu. Tersane-i Âmire Nakkaşbaşılığına yapılan iki tayin örneği için bkz. BOA, Cevdet Tasnifi Bahriye Evrakı (C.BH), nr. 11400, 27 Eylül 1759; C.BH, nr. 1755, 26 Ağustos 1791. XIX. yüzyılda Tersane bünyesinde boya imalathanesi olarak kullanılan bir nakkaşhanenin varlığına dair ise bkz. BOA, Sadâret Mektubî Kalemi Nezâret ve Devâ'ir Evrakı (A.MKT.NZD), 33/19, 27 Nisan 1851; BOA, Yıldız Mütenevvî Maruzât Evrakı (Y.MTV), 120/108, 23 Mayıs 1895. Aynı şekilde Tophane-i âmire bünyesinde de bir nakkaşhane mevcuttu. Farklı tarihlerde burada yapılan tamiratlar için bkz. BOA, İrâde-Dâhiliye Evrakı (İ.DH), 815/65819, 20 Ekim 1880; 1115/87206, 9 Aralık 1888; İrâde-Tophâne-i Âmire Evrakı (İ.TPH), 14/7, 19 Nisan 1905. 
17. yüzyıl süresince sayıları 40-50'yi, 18. yüzyılda ise 7-8 kişiyi geçmeyen Hassa nakkaşların İstanbul'daki tüm nakış işlerini gerçekleştirmeleri mümkün değildi. Şehirde, sanatlarıyla alakalı halkın ihtiyaçlarını karşılayan ve sayılarının çok daha kalabalık olduğunu tahmin ettiğimiz başka nakkaşlar da mevcuttu. Evliya Çelebi, seyahatnamesinde 17. yüzyıl İstanbul esnafını tanıtırken bu nakkaşlar için "Esnaf-1 nakkāşân-1 cihân” başlığı altında şu bilgileri verir: "Kârhâne-i nakkāşbaşı birdir, Arslanhâne'nin üst tabakaları kat-ender-kat kârgîr binâ hücreleridir kim cemî'-i nakkāşân-1 üstâdân bu kârhânede sâkindir gayrı yerlerde dükkân yüz adeddir ammâ hânelerinde sâkin saray-1 âlîler nakkāşı cümle bin neferdir." ${ }^{52} \mathrm{Bu}$ ifadelerden, Arslanhanenin üst katındaki odaların Nakkaşbaşı kârhanesi olarak kullanıldığı ve tüm usta nakkaşların bu kârhanede çalıştığı, şehirde yüz adet nakkaş dükkânı olduğu ancak dükkân sahibi olmayıp hanelerinde sakin bin kişilik de bir Saray nakkaşı topluluğu bulunduğu anlaşılır.

Evliya, verdiği bu bilginin ardından Nakkaşbaşıya yamak 17 esnaftan bahseder. Bu yamak esnaflar, kendilerine en yakın, güçlü ve de eski işkolu olan nakkaş esnafının başındaki Nakkaşbaşıya bağlı olarak faaliyet gösterirlerdi. Seyahatnamede dükkân ve çalışan sayılarının da belirtildiği bu esnaflar; altın döğücüler, müzehhipler, mücellitler, sahaflar, kâğıtçılar, mukavvâ kubur-divitçiler, remilci ve mektupçular, mürekkkepçiler, ressam nakkaşlar, ressam falcılar, oymacılar, Sûr-1 hümâyun nahılcıları, alcı ve balcılar, yastık basmacıları, çit basmacıları, sırma nakışçıları ve yağlıkçı nakkaşlard1. ${ }^{53}$ Metin And'ın “çarşı ressamları" olarak nitelendirdiğ $i^{54}$, çarşıda dükkânları olan ve müşterilerin ismarladığı konularda resimler yapan halk ressamları da muhtemelen bu grup içerisinde yer alıyordu.

Evliya Çelebi'nin, nakkaş esnafıyla ilgili vermiş olduğu 100 adet dükkân sayısını doğrulayabilecek bir veriye sahip değiliz. Ancak Hassa Nakkaşbaşının gözetiminde Arslanhanenin üst katındaki nakkaş atölyelerini kullanan bu nakkaşların tâbi oldukları bir nizamlarının olduğunu biliyoruz. Sultan I. Ahmed (1603-1617) devrinde kayıt altına alınan ve yaklaşık

\footnotetext{
${ }^{52}$ Evliya Çelebi b. Derviş Muhammed Zıllî, Evliya Çelebi Seyahatnamesi, haz. Orhan Şaik Gökyay, İstanbul 1996, I, s. 291.

${ }^{53}$ Evliya Çelebi Seyahatnamesi, I, s. 291-293.

${ }^{54}$ Metin And, “17. Yüzyıl Türk Çarşı Ressamları", Tarih ve Toplum, Sayı 16 (Nisan 1985), s. 40-45.
} 
iki yüz yıl yürürlükte kaldığı anlaşılan bu nizamın içeriğini oluşturan maddeler şunlard1: $:^{55}$

1. Nakkaşa bağlı işlenen bazı eşya Nakkaşbaşı marifetiyle (vasıtasıyla) görülüp (işlenip), yaramaz ve alçak (kötü ve değersiz) nakış işleyenlerin hâkim marifetiyle cezalarının verilmesi, ihtimam olunması.

2. Bazı pay (parça) işleyenler, nakkaş taifesinden ehil olmadan hizmet edenler, tekmîl-i sanat edip başka çıkmadan işleyenler ve bu nevi ustaya hizmet edip ehliyetsiz olan nakkaşlar dahi işlerler ise Nakkaşbaşı marifetiyle cezalandırılması.

3. Mahmutpaşa'da olan nakkaşların, Nakkaşbaşı narh vermedikçe diledikleri fiyata satıs yapmamaları.

4. Pay işleyenlerin Nakkaş kârhanesinden başka yerde işlememesi, işledikleri takdirde Nakkaşbaşı marifetiyle işlemeleri.

5. Çırakların Nakkaşbaşı marifetiyle seçilmesi, ehil olmayan kimselerin alınmaması.

6. Sancak ve bayrakların nakşolunması gerektiğinde, kanun gereği Nakkaşlar kârhanesinde Nakkaşbaşı marifetiyle işlenmesi, başka bir yerde asla işlenmemesi.

Nizamın sonunda ise Nakkaşbaşının emir talebine neden olan hususlar vurgulanıyordu. Bunlardan ilki, Mahmutpaşa Çarşısındaki kutucu taifesinin kutuya gümüş işlemeleri defalarca yasaklandığı halde bunu yapmakta ısrar etmeleriydi. İkincisi ise yabancı gemilerle Avrupa, İran, Karadeniz'den gelen $n e f t i^{56}$ önce Nakkaşbaşı gidip görür ve saray için lâzım olan miktarı satın alırken, Yahudi taifesinin herkesten önce giderek alması ve piyasada darlık yaratarak fiyat yükseltmeleriydi. Sonuçta Nakkaşbaşının, nizamı hatırlatarak sıkıntıları aktardığı arzuhal ile nizama ve yasaklara uymayanların cezalandırılması yönünde çıkartılmasını sağladığı bu emir 17. yüzyıl başlarından itibaren iki yüzyıl geçerliliğini korudu.

${ }^{55}$ Sultan I. Ahmed devrinde verildiği belirtilen bu nizam, daha sonra tahta çıkan hükümdarlar tarafından yenilenmeye devam etmiştir. Elimizdeki bilgilere göre nizamın 19-28 Şubat 1721 ve 30 Aralık 1731 (BOA, MAD.d, nr. 8947, s. 116/1-2) ve 6-15 Ocak 1782 [BOA, Bab-1 Asafî Divân-1 Hümâyun Sicilleri İstanbul Ahkâm Defterleri (A.DVNS.AHK.İS.d), nr. 10, s. 105/398] tarihlerinde yenilendiği görülmektedir.

${ }^{56} \mathrm{Neft}$ : Yerden çıkan ve çam gibi bazı ağaçlardan çıkarılan yanmış bir yağ ki boyacılıkta

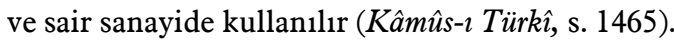


Çıraklıkları süresince tekmîl-i sanat eden yani sanatlarında olgunlaşan/yetkinleşen ve başka çıkma/çlkarlma olarak adlandırılan yöntemle çıraklıktan kalfalığa yükseltilen nakkaşlarla ilgili bu nizam, "Çarşı nakkaşları" olarak da nitelendirebileceğimiz nakkaş esnafı hakkında kıymetli bilgiler içermektedir. Nakkaşbaşının, bazı eşyaların işlenmesinde, kötü nakış işleyenlerin ve ehliyetsiz nakkaşların cezalandırılmasında, fiyat tespiti ve çırak seçiminde etkin bir rol üstlendiği görülmektedir. Ayrıca, sancak ve bayrakların nakşının nakkaş kârhânesi dışında işlenmesinin kanunen yasak olduğu bilgisi verilmektedir. Bu bilgi, şehirdeki nakkaş esnafınca çalışma atölyesi olarak kullanılan bir nakkaşhanenin varlı̆̆ını net bir şekilde ortaya koymaktadir.

Vezir, beylerbeyi, ümera, kadılar ve müderrislere verilen beratlar, yabancı hükümdarlara gönderilen mektuplar ve fermanlara çekilen tuğraların tezhip edilerek süslenmesi Nakkaşhanedeki Hassa nakkaşlara mahsustu. Saray dışındaki müzehhip dükkânlarında tuğraların tezhiplenmesi yasakt1. ${ }^{57}$ Arapça'da "altınlamak" manasına gelen tezhip kelimesi, ezilerek firçayla sürülecek hale getirilmiş olan varak altın ve muhtelif renklerin kullanılmasıyla gerçekleştirilen bir kitap sanatıyd. ${ }^{58}$ Altın varak, Hassa nakkaş, mücellit ve Divân kâtiplerinin süsleme sanatında kullandıkları önemli malzemelerden biriydi. İstanbul'daki varakçllar tarafından belli kalıplara göre işlenir ve deste üzerinden satılırdı. 1573 yılında, varakçıların başına Divân-1 hümâyun tarafından bir kethüda ve yiğitbaşı tayin edildi. Bu uygulamanın nedeni, altın varağı büyük kalıba işleyip destesini 15 akçeye satmas1 gereken varakçların, küçük kalıp kullanmaları ve altını tam işlemeyip ham iken kalıba dökmeleri, çoğu varakları kaleme gelmeyecek şekilde delikli olarak işlemeleri ve üç dört parçaya bölüp dışarıdan gelen tüccara yüksek fiyata satmalarıydı. Öncelikli olarak kendi ihtiyaçlarının karşılanması gerektiğini ve çoğu zaman altın varak tedarikinde sıkıntı yaşadıklarını belirten nakkaş, kâtip ve mücellitler; İstanbul'daki varakçıların başına bir kethüda ve yiğitbaşı tayin edilmesi, haftada dört deste varağın kendilerine

${ }^{57}$ 4-13 Temmuz 1693 tarihli emir için bkz. Ahmed Refik, Onikinci Asr-ı Hicrî̀de İstanbul Hayatı (1689-1785), İstanbul 1988, s. 9.

${ }^{58}$ Klasik usulde, zarlar arasına konulup dövülerek elde edilen ve kalınlığı mikronla ölçülebilen $5 \times 10 \mathrm{~cm}$. ebadındaki on varak altına bir deste, yirmi desteye ise bir tefe denirdi (Çiçek Derman, "Türk Tezhip Sanatının Asırlar İçinde Değişimi”, Türkler, Ankara 2002, XII, s. 289-290). 
ve devletle ilgili işlerde hazır bulunmak üzere yiğitbaşılarına teslim edilmesi yönündeki arzuhalleriyle Divâna başvuruda bulundular. İsteklerinin kabul görmesi üzerine İstanbul Kadısına hitaben yazılan emirle, varakç1lardan Silahtar Hüsnü'nün kethüda, Sinan'ın da yiğitbaşı olarak tayin edildiği ve varakçılarla birlikte huzuruna getirtilerek aşağıda içeriği belirtilen emre harfiyen uymaları konusunda tembihte bulunması istendi.

1. Varakçıların, eskiden olduğu gibi altını büyük kalıba işleyip destesini on beşe, gümüş varağın destesini de beş akçeye satmaları.

2. Varăğ iyi altından tam ve düzgün bir şekilde işleyip, ham iken satmamalar1.

3. Divân-1 hümâyun kâtipleri, Hassa nakkaşlar ve Sarayla alakalı tüm işlerde altın varağın daima hazır bulunması için her bir varakçının haftada dörder deste varağı getirip yiğitbaşılarına teslim etmeleri ve paralarını da ondan almaları.

4. İşledikleri varağı, İstanbul'da altın varak kullananlar kâfi miktarda almadıkça hariçten kimseye satmamaları.

5. Kethüda ve yiğitbaşıların bu hususlarda gereken kontrolleri yapmak ve aksi tutum sergileyenleri İstanbul Kadisına bildirmekle mükellef oldukları.

Deste olarak işlenen ve satılan varakta kullanılan altın 16. yüzyılda sikke üzerinden hesaplanır, bir sikke altından dört deste varak işlenirdi. 1590 yılında, dört destenin üzerinde varak işlendiği yönünde şikâyetler gelmesi üzerine, altın varak işleyen altıncılar taifesine Hassa Nakkaşbaşının nazır, nakkaşlardan birinin de kethüda olarak tayin edilmesine karar verildi. ${ }^{60} \mathrm{Bu}$ tayin, Hassa nakkaşlar cemaati içerisinde 16 . yüzyıl sonlarından itibaren görülen kethüdalık uygulamasını daha anlaşılır kılmaktadır.

\footnotetext{
${ }^{59} 23$ Ekim 1573 tarihli emir için bkz. Ahmed Refik, Onuncu Asr-ı Hicrî̀de İstanbul Hayatı (1495-1591), İstanbul 1988, s. 111-112.

${ }^{60} 30$ Ekim 1590 tarihli emir için bkz. A. Refik, İstanbul Hayatı (1495-1591), s. 135-136. Altın varak, Donanma-yı hümâyun gemilerinin tezyinlerinde de aranan bir malzemeydi. Tersane-i âmire Nakkaşbaşısı marifetiyle her yıl kâfi miktarda altın varak İstanbul'daki altıncı esnafından satın alınırdı (BOA, C.BH, nr. 5745, 21 Mayıs 1787). Aynı şekilde Kayıkhane-i hassada mevcut kayıkların altı ayda bir ikişer takım küreklerinin yaldızlanmasında da altın kullanılırdı (BOA, C.SM, nr. 5135, 22 Kasım 1777).
} 
İstanbul'da, Ehl-i hirefe mensup Hassa nakkaşlar ve dükkân sahibi nakkaş esnafı dışında sayıları çok daha kalabalık bir nakkaş grubu daha vardı. Bunlar, amele sınıfı içerisinde yer alıp şehirdeki mirî, dinî ve sivil yapıların inşa ve tamiratlarında çalışarak sıva üstü boyalı nakışlarını gerçekleştiren nakkaşlardı. Evliya Çelebi, eserinde bu nakkaşlarla ilgili net bir ayrımda bulunmaz. Nakkaş esnafının yüz adet dükkân sayısını verir fakat çalışan sayısını belirtmez. Sonra da "Ammâ hânelerinde sâkin saray-1 âlîler nakkāşı cümle bin neferdir” ifadesini kullanır. Ardından esnaf pîrlerinden ve onların tarihte bazı meşhur dinî yapılarda yaptıkları nakışlardan bahseder. Hatta Emeviler döneminde nakkaşlar pîri olan Abbas oğlu Fazl'ın, Emeviye Camii'nin kubbesini nakşederken gözüne kireç tozu kaçmasından dolayı düşüp öldüğünü anlatır. ${ }^{61}$ Evliya'nın vermiş olduğu örnekler, kanaatimizce bir önceki ifadeyle yani hanelerinde sakin bin nefer saray nakkaşıla bağlantılı ve bunların yapılarda çalışan nakkaşlar olduğu bilinciyle verilmiş olmalıdır.

18. yüzyıla ait bazı Osmanlı belgelerinde, "Ehl-i hirefe tâbi“ nakkāşân1 hâssa ve tevâbi'i neferâtı müstakill bir ocak olup" şeklinde geçen bir ibareye rastlanmaktadır. ${ }^{62} \mathrm{Bu}$ ibare, Ehl-i hiref çatısı altında faaliyet gösteren Saray nakkaşları ve onlara bağlı kimselerden müteşekkil müstakil bir birimi tanımlamaktadır. Osmanlı mimarisinin boyalı nakış sanatkârları olan nakkaşlar işte bu birimin mensuplarıdır ve Hassa nakkaşlara bağlıdırlar. Bu yüzden kimi belgelerde "nakkāşân-1 hassa neferâtı" olarak da geçerler. Sarayla olan bağlantıları, Evliya'nın onları neden evlerinde sakin bin kişilik Saray nakkaşları olarak nitelediğini açıklamaktadır. Bu dönemdeki sayıları hakkında elimizde net bir veri bulunmasa da başkent İstanbul'un tüm yapım onarım faaliyetleri göz önüne alındığında kalabalık bir nüfusa sahip oldukları tahmin edilebilir. Yetişme ve çalışma nizamlarına dair düzenli bilgilere ise 18. yüzyıldan itibaren rastlanmaktadır.

Ehl-i hiref çatısı altında yer aldıklarından dolayı Hassa nakkaşlar gibi Enderun Hazinedarbaşısına tâbi olan bu nakkaşların ustalık, kalfalık ve çıraklık nizamlarının 1742 yılında tadilata uğrayarak kayıt altına alındığı

\footnotetext{
${ }^{61}$ Evliya Çelebi Seyahatnamesi, I, s. 291.

${ }^{62}$ BOA, MAD.d, nr. 8947, s. 90, 14 Nisan 1764.

${ }^{63}$ BOA, Cevdet Tasnifi Maarif Evrakı (C.MF), nr. 5605, 2-11 Aralık 1796.
} 
görülmektedir. ${ }^{64}$ Nedeni, yürürlükteki nizamın bozularak artık uygulanamaz hale gelmesi ve yeni bir düzenlemenin gerekliliğidir. Nizamlarına göre, Nakkāşân-ı hassa neferâtının tüm işleri eskiden beri Nakkaşbaşı olanlar marifetiyle görülürdü. Nakkaş ustalarından çırak almayı hak edenler, ancak "ihtiyar ustalar" denilen mesleğin ileri gelen tecrübeli ustalarının ittifakı, Nakkaşbaşının izni ve marifetiyle çırak alabilirlerdi. 18. yüzyıl ortalarına doğru bu düzenin bozularak ortadan kalkmasına yol açan şikâyet konuları ise şunlardı:

1. Nakkaşân-ı hassa neferâtından bazılarının yeniçeri, cebeci, topçu, top arabacı, mehter ve seyitlik iddiasıyla ihtiyarlarına ve Nakkaşbaşılarına itaat etmeyip bildikleri ve diledikleri gibi izinsiz çırak almaları ve diğer nakkaşların da onlara kıyas ile "Bizler de teferrü ${ }^{65}$ gördük" (çıraklıktan çıktık) diyerek sakal bırakmaları.

2. Ehil olmayanların ve tıraş olanların çırak almaları.

3. Teferrüc görenlerin sadece başka çıkma ve başka iş alma hakları varken izinsiz çırak almalarının nizamlarına aykırı olduğu.

4. Hâlâ içlerinden haşerât (zararlı kimseler) zuhur etmesi ve bunların itaatten çıkması. Bu şekilde çırak olan ehliyetsiz kimselerin [daha sonra kendi] çıraklarına, tekmîl-i sanat etmeden kısa zamanda izin vermeleri.

5. Bu şekilde, gerekli hizmetlerinin terkedilerek eskiden beri uygulanagelen nizamlarının bozulup karmakarışık olması.

Hassa Nakkaşbaşı Ali'nin arz ettiği bu hususlar ve nizamda önerdiği değişiklikler, Enderun Hazinedarbaşısı Ahmed'in mektubuyla Sadarete bildirildi. Yeni düzenlemenin kabul edilmesi üzerine çıkan ferman, uygulanması için İstanbul, Galata, Haslar ve Üsküdar Kadılarına gönderildi. Bu düzenlemede, çırak alımı ve yetiştirilmesine dair yaşanan problemlerin çözümüne yönelik alınan kararlar şunlardı:

\footnotetext{
${ }^{64} 29$ Kasım-8 Aralık 1742 tarihinde getirilen düzenleme (BOA, A.DVNS.AHK.IS.d, nr. 1, s. 51/232), 2-11 Aralık 1796'da yenilendi (C.MF, nr. 5605; A.DVNS.AHK.İS.d, nr. 13, s. 65/204).

${ }^{65}$ Teferrüc: Açılma, ferahlanma (Kâmûs-ı Türk̂, s. 421).
} 
1. Nakkaşân-ı hassa neferâtından sakallı olup ehliyetsiz olanların ve sakalını tıraş eden kimselerin bundan sonra çırak almaması.

2. Çırak alma hakkına sahip olan ustaların üç seneden önce çıraklarına izin vermemesi, üç seneden önce izin verilen çırakların tekrar ustalar marifetiyle tekmîl-i sanat için tecrübeli bir ustaya verilmesi.

3. Çıraklarını başka çıkarıp izin veren ustaların bir sene dolana dek çırak almamasi.

4. Nizama aykırı hareket edenlerin önlenmesi, uslanmayanların Nakkaşbaşı marifetiyle cezalandırılması.

Esnaf teşkilâtının en alt kademesinde yer alan şâkird ya da çıraklar, çalıştıkları sanat dalının inceliklerini öğrenmek için bir ustaya tâbi olmak zorundaydılar. Ustasının yanında belli bir süre çalışarak sanatını öğrenen ve kendini ispatlayan çırak, ancak ustasının "destur verme" olarak adland1rılan onay ve izniyle çıraklıktan çıkabilirdi. Bu izin, nakkaşlarla ilgili nizamda "teferrüc görme" tabiriyle belirtilmekteydi. "Başka çıkma ve başka iş alma" ise daha önce de ifade ettiğimiz gibi çıraklıktan kalfalığa yükselerek ustasından bağımsız iş alabilme hakkıydı. Çırak alma ve yetiştirme sadece ustalara tanınan bir imtiyaz olduğundan, nizamda geçen "Teferrüc görenlerin sadece başka çıkma ve başka iş alma hakları varken izinsiz çırak almalarının nizamlarına aykırı olduğu" ibaresi de "başka çıkan" nakkaşların ustalığa değil kalfalığa yükseldiğini ve bu şekilde çırak alamayacaklarına işaret etmekteydi. Sakal bırakmak ise ustalara mahsus bir haktı. Sakalsız olanların ve sanatında ehil olmayan sakallı ustaların çırak alması yasaktı.

Farklı askerî sınıflara mensup nakkaşların, statülerine güvenerek merkezî otoritenin koymuş olduğu kanunlara karşı gösterdikleri lakayt ve keyfî tutum, sadece çırak alımı ve bu çırakların yetişmelerini değil, yapılardaki çalışma nizamlarının işleyişini de olumsuz etkilemekteydi. Eskiden beri uygulanagelen nizamlarına göre nakkaşlar, işini yapmayı taahhüt ettikleri binaları götürü usulüyle (sabit maliyet) alır ve çeşitli boyalarla boyayarak nakşederlerdi. Fakat 1768 yılında, hâm-dest ve mechûlü'l-ahvâl olarak nitelendirilen beceriksiz ve neyin nesi olduğu bilinmeyen kimselerin bir şekilde içlerine dâhil olmaya başlaması şikâyet konusu oldu. Bu nakkaşların, götürü aldıkları binaları kalb ü redî (hileli ve kötü) boyalar ile boyamaları ve yeni boyanan binaların aradan birkaç gün geçtikten sonra kötü bir hal al- 
ması bina sahiplerine büyük zarar vermekteydi. Ayrıca, yaşanan sıkıntılar esnaf mensupları arasında kavga ve çekişmelere, nizamlarının da bozulup ortadan kalkmasına neden olmaktaydı. Bunun üzerine başta Nakkaşbaşı olmak üzere mesleğin önde gelen nakkaş ustaları İstanbul Kadısına müracaat ederek, şikâyetlerinden bahisle nizamlarında değişiklik yapılmasını talep ettiler. Üzerinde anlaşarak karara varılan hususlar şunlardı:

1. Bundan sonra götürü bina almanın yasaklanması.

2. İstanbul'da hizmet ile sanatlarını öğrenip hak etmedikçe, sanatlarıyla alakası olmayan beceriksiz ve neyin nesi olduğu bilinmeyen kimselerin içlerine girmemesi, sanatlarına karışmaması.

3. Esnaftan olanların dahi bundan sonra götürü yapı almayıp boya ve sair lâzım olan malzemeyi bina sahiplerinin kendilerinin alması, esnaftan olanların asla karışmaması.

4. Ancak gündelik ile işlemenin kavgaları sona erdireceği ve bunun halkın yararına olduğu.

Nakkaşlar, aralarında anlaşıp sözleştikleri bu yeni düzenlemeye uymayı, daima geçerli bir kanun olarak yürürlükte tutmayı ve aykırı hareketlerde bulunmamayı taahhüt ettiler. Ayrıca içlerinde yeniçeri, cebeci, topçu ya da bostancı olup nizamın şartlarına aykırı hareket edenlerin, zabitleri marifetiyle cezalandırılarak esnaflıktan atılmasına razı olduklarını beyan ettiler. Sonuçta, yapılan düzenlemenin halkın yararına olduğu yönünde İstanbul Kadısının olumlu görüş bildirmesi üzerine verilen emirle nakkaş esnafının yeni nizamı kabul edilerek yürürlüğe girdi. ${ }^{66}$

1768 nizamı nakkaşlar için aslında radikal kararlar içeriyordu. O tarihe kadar uygulanan götürü usulünün yerine gündeliğin getirilmesi ve boya alımının bina sahiplerine bırakılması yaşanan sıkıntının büyüklüğünü gösteriyordu. Alınmaya çalışılan önlemlerin pratikte ne ölçüde uygulanabildiğini bilemiyoruz. Ancak, bu tarihten itibaren altı yıl süren Osmanl1Rus savaşı sırasında devletin içinde bulunduğu malî kriz ve artan enflasyon

\footnotetext{
${ }^{66} 26$ Ağustos 1768 tarihli nizam, cülus münasebetiyle 23 Aralık 1781'de yenilendi (BOA, MAD.d, nr. 8947, s. 91).
} 
neticesinde oluşan mal ve hizmet fiyatlarındaki yükselişin şehirdeki denetimi ve nizamın işleyişini güçleştirdiğini tahmin edebiliriz.

İstanbul'da, yapıların inşa ve tamiratında etkin bir zümre daha vardı ki o da Hassa Bostancı Ocağıydı. Bu ocak içerisinde yer alan Hasbahçeye tâbi nakkaşân, meremmatcıyân, sivacıyân ve taşçıân ocaklarının mensupları eskiden beri Saray-1 hümâyunun Hırka-i şerif, Harem-i hümâyun ve sair mahallerinde, Selâtin camilerinde ve gerektiğinde Mekke ve Medine'de vuku bulan tamiratlarda istihdam edilirlerdi. Ayrıca Bostancıbaşının sorumluluk alanına giren Boğaziçi ve Surdısındaki yalıların, Saray bahçelerindeki yapıların yapım ve onarım faaliyetlerinde bulunurlard ${ }^{67}$

İstanbul dâhilinde ve hâricinde yani Suriçi ve Surdışı İstanbul'unda yeni yapılan binaların nakış ve boyası eskiden beri Hassa Nakkaşbaşı marifetiyle görülür iken, Hassa Bostancı Ocağı meremmatcıları Sultan III. Ahmed zamanında (1703-1730) çıkarttıkları bir emirle Surdışındaki binaların nakşını tasarruflarına aldılar. Hassa Nakkaşbaşı, sorumluluk alanına müdahale olarak gördüğü bu emri kabul etmek istemedi. Emrin, bir şekilde eski uygulamalara aykırı olarak alındığını, hâm-dest (eli işe yatmayan, beceriksiz) bostancıların halka ait binaları kalb (hileli) boyalarla nakşederek sanatlarının ve nizamlarının bozulmasına neden olduklarını ileri sürdü. 1723 yılında, Hassa Nakkaşbaşının bu doğrultudaki arzuhali ve bağlı bulundukları Enderun Hazinedarbaşısının Divâna sunduğu arz üzerine, bundan sonra söz konusu sorumluluk alanlarına Bostancı Ocağı meremmatcılarının kesinlikle müdahale etmemelerine dair İstanbul Kadısına, Bostanc1başıya, Haslar, Galata ve Üsküdar Kadılarına hitaben bir emir yazılmasına muvaffak oldular. ${ }^{68}$

Sultan III. Ahmed döneminde, Surdışında inşa edilen yapılardaki artan nakkaş ihtiyacının İstanbul nakkaşlarıyla Bostancı ocağı arasında bir nüfuz ve hâkimiyet mücadelesine dönüştüğü anlaşılıyor. Nitekim merem-

${ }^{67}$ BOA, C.BLD, nr. 6817; MAD.d, nr. 8947, s. 60, 25 Ağustos 1785. Geniş bilgi için bkz. Murat Yıldız, Bahçıvanlıktan Saray Muhafızlı̆̆ına Bostancı Ocă̆ı, İzmir 2011, s. 160162.

${ }^{68} 10$ Ocak 1723 tarihli emir (BOA, MAD.d, nr. 8947, s. 85/1), 1144/1731-1732 ve 30 Nisan 1765 (MAD.d, nr. 9994, s. 283/3) ve 17 Temmuz 1775 (MAD.d, nr. 8947, s. 90/2) tarihlerinde yenilendi. 
matcıların dışında, yine Hasbahçeye tâbi bir ocak olan Nakkaşlar ocağ mensupları ve başlarındaki Bostancı Ocağı Nakkaşbaşısı da bu mücadelenin içerisindeydi. İstanbul'da, Surdışındaki yalıların birinde nakkaş işi düştüğünde önce Bostancıbaşıdan izin alınır ve ardından Ocağın Nakkaşbaşısı Bostancı nakkaşlarıyla birlikte işi gerçekleştirirdi. Suriçi İstanbul'unda, şehrin nakkaş ustaları tarafından işlenen nakkaş işlerine Bostancı Ocağ 1 Nakkaşbaşısı karışmadığı gibi Surdışındaki işlere de onlar müdahale etmezlerdi. III. Ahmed zamanında, İstanbul nakkaşlarından bazılarının kendi kazançlarına kanaat etmeyip bostancılara musallat olmaları ve "Yalılardaki nakkaş işini size işletmeyiz" diyerek eskiden beri uygulanagelen nizama aykırı hareket etmeleri Bostancı Ocă̆ı Nakkaşbaşısının şikâyetine neden oldu. Ocağın kanun bilir, kıdemli, tecrübeli ve güvenilir mensuplarından konu soruşturuldu ve sonuçta, Surdışındaki yalıların nakkaş işlerinin Bostancı Ocağı Nakkaşbaşısı marifetiyle işlenegeldiği, İstanbul nakkaşlarının Bostancıbaşı tarafından izinli olmadıkça buralarda çalışmamaları ve müdahalede bulunmamaları yönünde Ocak Nakkaşbaşısının arzuhali ve Bostancıbaşının ilamı üzerine gereken emir verildi. ${ }^{69}$

Devlet, işçi ücretlerinde de belirleyici ve denetleyici konumdayd. Mimarbaşı, yapı esnafı ve yapı malzemeleriyle ilgili düzenlemeleri yapmak ve uygulamakla vazifeli olduğu gibi amele sınıfı içerisinde yer alan usta, kalfa ve çırakların gündeliklerini tespit etmekle de mükellefti. ${ }^{70}$ Fiyat istikrarının sağlanması, halkın sıkıntı yaşamaması, mağduriyet ve suiistimallerin önlenmesi amacıyla gereken denetimlerin yapılması İstanbul Kadısı ve Mimarbaşıdan talep edilirdi. Devletin belirlemiş olduğu işçi ücretlerinin, ülkenin içinde bulunduğu ekonomik koşullara ve şehrin yaşadığ 1 afetlere bağlı olarak çoğu zaman piyasa fiyatlarının gerisinde kalışı, bu konudaki şikâyet, emir ve düzenlemeleri yüzyıllar boyunca karşımıza çıkarmaktadır.

\footnotetext{
${ }^{69}$ Sultan III. Ahmed zamanında verilen bu emir, 20-29 Mart 1731 ve 18-27 Ağustos 1765 (BOA, A.DVNS.AHK.IS.d, nr. 7, s. 229/692, 9-18 May1s 1778; nr. 9, s. 251/956 ve 9-18 Ağustos 1793; nr. 12, s. 75/220) tarihlerinde yenilendi.

${ }^{70}$ Şerafettin Turan, "Osmanlı Teşkilâtında Hassa Mimarları”, AÜDTCF Tarih Araşttrmalar Dergisi, I/1 (1963), 174-175; Cengiz Orhonlu, "Şehir Mimarları”, Osmanlı Araşttrmalar, İstanbul 1981, II, 8.
} 
Nakkaş yevmiyelerine dair kayıtlara, diğer amele sınıflarında olduğu gibi 18. yüzyıldan itibaren daha düzenli olarak rastlanmaktadır. Osmanlı

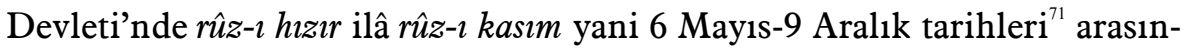
daki yedi aylık dönem inşaat mevsimi olarak bilinirdi. Bu dönemdeki ame-

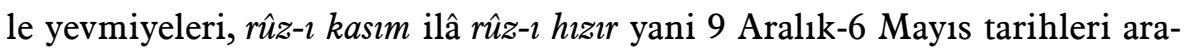
sındaki beş aylık döneme göre daha yüksek olurdu. 1723 yılında, yapılarda çalışan nakkaş ustası yevmiyesinin 50, kalfa yevmiyesinin ise 40 akçe olmasına karar verilmişti. Hassa Mimarbaşı, başlangıçta nakkaş ustası yevmiyesini neccarlarla eşit yani 40 akçe olarak belirlemek istediyse de yaptıkları işler denk görülmediğinden bu isteği kabul edilmemişti. ${ }^{72}$ Sonraki ylllarda gerçekleştirilen ücret düzenlemeleri incelendiğinde, İstanbul'da vuku bulan yangın ve deprem gibi doğal afetler sonucu ortaya çıkan amele açığının ücretlerde ciddi artışlara neden olduğu görülmektedir. Nitekim bu tür gerekçelerle 1750 yılında nakkaş ustası yevmiyesi \%30’luk bir artışla 65 akçeye yükseltildi. ${ }^{73}$ On dört yıl sonraki 1764 yılı ücretlerinde ise usta yevmiyesinde değişikliğe gidilmemekle birlikte çırak yevmiyesi 40 akçeden 50 akçeye çıkarıld1. ${ }^{74}$

1768-1774 Osmanlı-Rus harbinin ekonomi üzerindeki tesiri yıkıcı oldu. Para ayarının bozulması ve artan enflasyon neticesinde mal ve hizmet fiyatlarındaki ciddi yükseliş 1779 yılında ücretlerde yeni bir düzenlemenin yapılmasını zorunlu kıldı. O tarihe kadar yevmiyelerde usta, kalfa ve çırak olmak üzere üç sınıfa ayrılan nakkaşlara, bu düzenlemede vasat ve sadeci nakkaşlar da eklendi. Ücret artış oranı 1764'e göre ustalarda \%100'ü buluyordu. ${ }^{75}$ Aşağıdaki tablo, 1723-1779 yılları arasında nakkaşlar için yaz aylarında tayin edilen yevmiyeleri göstermektedir.

\footnotetext{
${ }^{71}$ Fehmi Yılmaz, Osmanlı Tarih Sözlüğü, İstanbul 2010, s. 550.

${ }^{72}$ BOA, MAD.d, nr. 8947, s. 90/3, 19 May1s 1723.

${ }^{73}$ BOA, MAD.d, nr. 8947, s. 101/1, 18-27 Şubat 1750.

${ }^{74}$ BOA, $M A D . d$, nr. 8947, s. 78, 24 Ekim 1764.

${ }^{75}$ BOA, MAD.d, nr. 8947, s. 40-41, 19 Nisan 1779.
} 
Nakkaş Yevmiyeleri (6 Mayıs-9 Aralık)

\begin{tabular}{lcccc}
\hline & $\mathbf{1 7 2 3}$ & $\mathbf{1 7 5 0}$ & $\mathbf{1 7 6 4}$ & $\mathbf{1 7 7 9}$ \\
\hline Nakkaş ustası & 50 akçe & 65 akçe & 65 akçe & 120 akçe \\
Nakkaş kalfası & 40 & & & \\
Nakkaş şakirdi & & 40 & 50 & 55 \\
Vasat nakkaş & & & & 90 \\
Sadeci nakkaş & & & & 75
\end{tabular}

Enflasyonun yanı sıra İstanbul ve Boğaziçi'nde artan inşaat faaliyetleri sonucu ortaya çıkan işçi açığı da ücretlerin yükselişinde önemli bir etkendi. Sultan II. Mahmud zamanında bu tür sıkıntılar öne sürülerek yevmiyelerde bir iyileştirme daha yapıldı. 1811 ve 1813 yıllarında yapılan düzenlemelerde, ücretlerde yaz-kış ayrımının ortadan kalktığı, akçe yerine paranın ${ }^{76}$ kullanıldığı, nakkaşların kalemkâr ve sadekâr, kalemkârların da usta ve bayă̆ı şeklinde ayrıntılı bir sınıflamaya tâbi tutulduğu ve Nakkaşbaşının da listede yer aldığı görülmektedir. ${ }^{77}$

\begin{tabular}{lcc}
\multicolumn{3}{c}{ Nakkaş Yevmiyeleri } \\
\hline & $\mathbf{1 8 1 1}$ & $\mathbf{1 8 1 3}$ \\
\hline Ser-nakkaşân & 100 para & 115 para \\
Üstad kalemkâr nakkaş & 95 & 110 \\
Bayağı kalemkâr nakkaş & 85 & 95 \\
Sadekâr nakkaş & 70 & 80 \\
Nakkaş şakirdi & 45 & 55
\end{tabular}

Devletin belirlediği resmî ücretlerle (narh) piyasada oluşan rakamlar arasındaki uçurumu ortadan kaldırmak, ne tür önlemler alınırsa alınsın, tüm İstanbul'da kontrol ve denetimi sağlayarak bunu uzun süre sürdürebilmek oldukça güçtü. Bu yüzden nakkaş esnafındaki tekelciliğe ve keyfî ücret taleplerine dair şikâyetler de hiçbir zaman eksik değildi. 4 Temmuz

\footnotetext{
${ }^{76}$ Kuruşun 1/40 oranına veya 3 akçelik miktara verilen isim ve hesap birimine para denilmektedir (F. Yılmaz, "Para”, Osmanl Tarih Sözlüğ̈̈, 522).

${ }^{77}$ BOA, C.BLD, nr. 2755; MAD.d, nr. 8956, s. 3, 24 Eylül 1811.
} 
1826 tarihinde, Yeniçeri Ocağının lağvedilmesinden yaklaşık yirmi gün sonra nakkaşlarla ilgili yeni bir düzenleme daha yapıldı. Hazırlıkları muhtemelen Ocağın lağvı öncesinde başlayan ve yaşanan sıkıntıların bir sonucu olarak ortaya çıktığı anlaşılan bu nizama duyulan ihtiyaç, çıkan fermanda şu gerekçelerle ortaya konuluyordu. ${ }^{78}$

1. Bir müddettir nakkaş esnafının nizamının bozulması ve sanatlarına dikkat etmemelerinden dolayı çoğunluğunun kalb (hileli boya ile kötü) işleyerek devlete ve halka zarar vermeleri.

2. Bir yerde bina yapıldığında, içlerinden biri boya nişân 1 (işareti) koyduktan sonra başkasını karıştırmayıp istediği gibi bina sahibini zarara sokmasi.

3. Başka nakkaş tedarik edilmek istendiğinde, yolsuz ederek (iş yaptırmayarak) işi tekellerine almaları.

4. Sıva üzerine nakşeden sıvacı esnafına yağlı boya sürdürmemeleri, süren olur ise yine yolsuz etmeleri.

Nakkaş esnafıyla ilgili bu şikâyetlerin ardından Bostancıbaşı, Şehremini ve Mimarbaşıdan kararlılıkla uygulamaları istenen yeni nizamın maddeleri ise şunlard1:

1. Bundan sonra esnaftan hiçbir ferdin bu tür istenmeyen hareketlerde bulunmamas1.

2. Götürü ya da gündelik ile istihdam olunan nakkaşların kalb işlememeleri.

3. Binalara boya nişân 1 koymamaları.

4. Râbıtalı ve hâlis (nizami ve hilesiz) boya ile işlemeleri.

5. Bina sahibinin, istediğini istihdam edip istemediğini de hesabını kapatarak Nakkaşbaşı vasıtasıyla bir başkasını çalıştırabilmesi.

6. İçlerinde kalb işleyenler çıkar ise zabiti marifetiyle cezalandırılmas1.

7. Bundan sonra, sıva üzerine nakş eden sıvacı esnafına da yağlı boya sürme izni verilip nakkaş esnafı tarafından buna muhalefet edilmemesi.

8. Bu uyarıların aksine hareket eden olur ise Nakkaşbaşının ihbarıyla başka bir mahalle defedilmesi.

${ }^{78}$ BOA, MAD.d, nr. 8947, s. 93, 4 Temmuz 1826. 
1826 düzenlemesinin üç ana konusu bulunuyordu. Birincisi meslekî tekelcilik, ikincisi malzeme ve işçilikteki sahtekârlık, üçüncüsü de sıvacı esnafına yağlı boya sürme izni. Bu düzenleme, nakkaşların yapılarda gündelikle çalışmanın yanı sıra götürü usulünü de sürdürdüklerini, sıvacıların ise sadece sıva değil sıva üzerine nakış da yaptıklarını ve bu dönem kalemişi nakışlarda yaygın olan yağlı boya kullanımında nakkaşlarla birlikte yer aldıklarını göstermektedir.

Sivacilar

Sıva, bir yapıda duvar ve tavan yüzeylerine, özelliklerine göre belirli kalınlıkta bir ya da birkaç kat olarak uygulanan kaplamaya denirdi. Yapıda farklı yerlerde değişik malzeme ve teknikle yapılan sıva, kullanıldığı yerlere göre "iç" ve "dış" olmak üzere ikiye ayrılırdı. ${ }^{79}$ Osmanlı İstanbul'unda, bu işi gerçekleştiren ve bir meslek olarak icra edenler çoğunlukla gayrimüslim sıvacılardı. Müslüman sıvacıların sayısı daha az olup geneli saray ve askerî zümre mensubuydu. Saraya bağlı olanlar, Yeni Saray yani Topkapı Sarayında hizmet eden Hassa sıvacılar ile Beyazıt'daki Eski Saray sıvacılarıydı. Her iki grup da devletin maaşlı kulları olup kurum olarak Matbah-1 âmireye tâbiydiler. Tayin ve terfileri ise Enderun-1 hassa Kilercibaşısının sorumluluğundaydı. Eski ya da Yeni Sarayda bir sıvacı öldüğünde, kadrosu ve göreve başlarken aldığı ilk maaşı Hassa sıvacılar arasında ulufesiz olarak hizmet edip kadro bekleyenlere, terakkileri ise içlerinde "hak edene" zam olarak verilirdi. ${ }^{80}$ Saraydan çıkarak çeră yani terfi edilmeleri halinde ise askerî zümrelerden birine tayin edilirlerdi. ${ }^{81}$ Fakat bu durum, onların sıvacılık mesleğini sürdürmelerine engel teşkil etmezdi.

Bir de Hasbahçeye bağlı Sıvacı Ocağı bulunuyordu. Bostancıbaşının sorumluluğundaki bu ocağın mensupları, daha önce de belirttiğimiz gibi Saray-1 hümâyunda, Selâtin camilerinde, Boğaziçi'ndeki yalılarda ve gerektiğinde Mekke ve Medine'deki inşa ve tamiratlarda Hasbahçenin meremmatcı ve nakkaşlarıyla birlikte istihdam edilirlerdi. Saray-1 hümâyunda sıva

\footnotetext{
${ }^{79}$ Halit Yaşa Ersoy, "Sıva”, Eczacıbaşı Sanat Ansiklopedisi, İstanbul 1997, III, s. 1658.

${ }^{80}$ BOA, AE.SAMD.III, nr. 5598, 28 Temmuz 1705.

${ }^{81} 8$ Mart 1706 tarihinde Hassa sıvacılardan üç kişiye Enderun-1 hassa kilercibaşısının arziyla sipahilik verilmesine dair bkz. BOA, AE.SAMD.III, nr. 6544.
} 
imali bu ocak tarafından gerçekleştirilir, bazen gerektiğinde yardım için gayrimüslim sıvacılar da çalıştırılırdı. ${ }^{82}$ Gayrimüslim sıvacılar arasında Yeni Saray ve Enderun'daki sofa, kasır ve çeşitli saray binalarının hurde (ince) sıva nakşını ve resimlerini işleyip musavvirlik (ressamlık) sanatında maharetlerini sergileyenler de olurdu. Sarayda uzun ylllar hizmet edip yeteneklerini çeşitli vesilelerle ispat eden bu sıvacılar, eski ya da yeni inşa edilmiş bazı saray yapılarının bakım ve onarımını ücretsiz yerine getirme taahhüdü karş1lığında vergilerden müsellem yani muaf tutulurlard.$^{83}$ Şehirde meslekî çoğunluğu ellerinde tutan gayrimüslim sıvacıların başında, kendi içlerinden seçtikleri ve Hassa Mimarbaşının arzı üzerine tayin edilen bir İstanbul Sıvacıbaşısı bulunurdu.

Evliya Çelebi, seyahatnamesinde İstanbul esnafını tanıtırken sıvacılara da kısaca değinir. Sayılarının 1.000 nefer olduğu ve sıva yapıp nakşettikleri bilgisini verir. ${ }^{85}$ Evliya'nın esnaf mensuplarıyla ilgili verdiği sayılar biraz abartılı olsa da günümüze ulaştırdığı bilgiler çok kıymetlidir. Nitekim sıvacıların sadece sıva değil, sıva üzerine nakış da yaptığı onun bu çok kısa açıklamasından teyit edilebilir.

18. yüzyıl İstanbul'unda sıvacı esnafının sayısı ve nizamları ile ilgili en teferruatlı bilgiyi 1776 yılında gayrimüslim sıvacıların İstanbul Kadısına yaptıkları bir şikâyet üzerine öğreniyoruz. Şikâyetin konusu, askerî zümre-

${ }^{82}$ BOA, MAD.d, nr. 8947, s. 59/2, 16 Haziran 1793.

${ }^{83}$ Gayrimüslim sıvacılardan Parsih veled-i Karabet, saraydaki on beş yılı aşkın hizmetinin ardından Enderun'daki sofa ve kasırların ve yeni inşa olunan kütüphanenin hurde sıva nakış ve resimlerinin bakım ve onarımını ücretsiz olarak yerine getirmeyi taahhüt ederek müsellemlik beratı almıştı (BOA, Bab-ı Defterî Maden Mukataası Kalemi Evrakı [D.MMK], nr. 174/77, 19 Ağustos 1725). Yine aynı şekilde, sarayda uzun yıllar hizmet etmiş gayrimüslim sıvacılardan Karabet veled-i Nursiz'in, Yeni Saraydaki Kirazlık Bahçesinde yeni yapılan kasrın ücretsiz meremmatcılığı hizmetinde bulunmak şartıyla müsellemlik talebi uygun görülmüştü (BOA, Ali Emirî Tasrifi Sultan I Mahmud Evrakı [AE.SMHD.I], nr. 11514, 3 Aralık 1746). Müsellemlik beratları hakkında bkz. Kemal Beydilli, "III. Selim Devrinde Verilen Bazı Muâf ve Müsellemlik Beratları Hakkında: Foti Kalfa'nın Berâtı”, Osmanlı-Türk Diplomatiği Semineri (30-31 Mayıs 1994) Bildiriler, İÜEF Tarih Araştırma Merkezi, İstanbul 1995, s. 75-89.

${ }^{84}$ Örnekler için bkz. BOA, Bulgaristan Devlet Arşivlerinden Alınan Osmanlıca Belgeler (YB.04.BLG.İST), nr. 4/45, 1 Ağustos 1725; C.IKTS, nr. 1445, 18 Temmuz 1727; AE.SMHD.I, nr. 3863, 3 Haziran 1740.

${ }^{85}$ Evliya Çelebi Seyahatnamesi, I, s. 299-300. 
lere mensup müslüman sıvacılardan bazılarının gayrimüslim sıvacıların işledikleri binaları zorla ellerinden almaları, gündeliklerini gasp ederek binalardan çıkartmaları, nizama riayet edenleri darp edip yaralamaları hatta öldürmeleriydi. Kendilerine büyük haksızlıklar yapılarak zulmedildiğini belirten gayrimüslim sıvacılar, mağduriyetlerinin önlenmesi ve yaptıkları işin düzgün bir nizama bağlanması için yardım talebinde bulundular. Bunun üzerine ilk olarak, müslim ve gayrimüslim sıvacılar sayıma tâbi tutuldu ve isimleri tek tek yazılarak kayıt altına alındı. Elde edilen sonuca göre İstanbul'da 57'si müslüman (\%18), 263'ü gayrimüslim (\%82) olmak üzere toplam 320 sıvacı mevcuttu. Müslüman sıvaciların hemen hepsi cebeci, bostanc1, yeniçeri, silahtar, sipahi, kalyoncu, topçu gibi askerî zümrelere mensuptu. Gayrimüslim sıvacıların ise tamamına yakını Ermenilerden müteşekkildi. Sayım sonrası İstanbul Kadısı huzuruna getirtilen her iki kesimin kethüda ve ustabaşıları, işledikleri binalara müdahalede bulunmamayı taahhüt ederek birbirlerine kefil oldular. Ayrıca nizamın devamı ve istikrarı için taraflar, olumsuz bir hareket vukuunda Ayasofya-i kebir Evkafına verilmek üzere 1.500 kuruş para cezasını (nezir) kabul ettiler. ${ }^{86}$

Problemin çözümüne yönelik ikinci aşama ise sıvacı esnafının öteden beri uyguladığı ancak uzun süredir terk edildiğini belirttikleri nizamlarının kayıt altına alınmasıydı. Bu doğrultuda, devletin kısa süre önce müslim ve gayrimüslim sıvacılar için ayrı ayrı atamış olduğu kethüda ve ustabaşılar başta olmak üzere, ileri gelen sıvacı ustaları bir araya getirtilerek nizamın şartları kaydedildi. İstanbul Kadısının ilamı üzerine, kendisine ve taraflara hitaben emirlerinin yazıldığı 1776 tarihli Sıvacı esnafı nizamının içeriğini oluşturan maddeler şunlard1 $1:^{87}$

1. Esnaftan ihtiyar ve hasta olan ustaların gözetilmesi.

2. Bir binada işe başlandığında, mal sahibinin rızasıyla bir usta bir havâle ${ }^{88}$ camı koyduktan sonra başka ustanın müdahale etmemesi.

\footnotetext{
${ }^{86} 10$ Mart 1776 tarihli sıvacı esnafı sayım defteri için bkz. BOA, Bâb-ı Defterî Başmuhasebe Kalemi Defterleri (D.BŞM.d), nr. 4628.

${ }^{87}$ BOA, MAD.d, nr. 8947, s. 60/1; A.DVNS.AHK.İS.d, nr. 8, s. 378/1230, 1-10 Nisan 1776.

${ }^{88}$ Bir işi veya bir şeyi birine bırakma, üstüne bırakma (Ferit Devellioğlu, OsmanlıcaTürkçe Ansiklopedik Lûgat, Ankara 1996, s. 344)
} 
3. Bir usta bir binayı mal sahibinden bâzâr (pazarlık) ederken başkasının karışmaması.

4. Yolsuz ve erkânsız (mesleği icrası yasaklanmış ve esnaf mensubu olmayan) olan kimsenin bir binaya baş olmaması.

5. Bir usta yirmi beş yıllık olduğunda çırak alması, üç sene bir çırağı çalıştırıp destur verdiğinde bir sene çırak almayıp beşinci senede almasi.

6. Müslim ustalar, bir binayı sahibinden pazarlık edip aldığında zimmîlerin müdahale etmemesi ve zimmîler aldığında da müslim ustaların karışmaması.

7. Esnafın sıva üzerine işledikleri yumurtalı ve yağlı boyalı nakşın kalb ü redî (hileli ve kötü) olmaması.

8. Müslim ile zimmîlerin bir binada mahlût (karışık) işlememesi.

9. Nizamın diğer şartlarının da aralarında daima düstûrü'l-amel ve mu'teber (kanun ve geçerli) tutulması, zikredilen şartların hilâfına hareket eden olur ise -gerek ehl-i İslâm ve gerek ehl-i zimmettenKadı marifetiyle gereken cezanın icra olunması.

İstanbul'da sıvacı esnafı arasındaki ihtilafların halli için yapılan sayım, bu mesleğin sanatlarında mahir Ermenilerin tekelinde olduğunu ortaya koymaktaydı. Müslim-gayrimüslim çatışmasının perde arkasında ise rant mücadelesi yatıyordu. Gayrimüslim sıvacılar, \%82'lik sayı üstünlüğü avantajıyla sanatlarını tekellerinde tutarak çıkarlarını koruma, müslüman sıvacılar da beraber iş yaparak bu ranttan daha fazla pay alma çabasındaydılar. Müslüman sıvacıların tamamının askerî sınıflara mensup oluşu ve statülerini baskı aracı olarak kullanmaları bu çatışmayı daha da artırmış ve 1776 yılında nizamla kayıt altına alınan bir ayrışmaya neden olmuştu. Nizam, sıvacıların çalışma şartlarıyla alakalı kıymetli bilgiler içermektedir. Müslim ve gayrimüslim sıvacıların yapılarda bir arada çalışmamaları ve birbirlerinin işlerini engellememeleri hususu nizamda çok net olarak belirtilmiştir. Ayrıca, bir binanın işini alan ustanın bunun işareti olarak yapıya havale camı koymasıyla ilgili kayıt, bu tür uygulamaların sadece nakkaşlarda değil diğer amele sınıflarında da görülebileceğine dair önemli bir örnektir. Ancak buradaki en önemli şart, nizamda da belirtildiği üzere yapı sahibinin iznidir. Sıvacı esnafının, sıva üzerine yumurtalı ve yağlı boyalı nakış işlediği bilgisi ise kalemişi nakışlarda yağlıboya kullanımının bu tarihlerde yaygın olduğunu göstermektedir. 
Müslüman sıvacılar, 1776 tarihli emrin iptali için ilki bir ay sonra olmak üzere iki yıl içerisinde tam üç kez İstanbul Kadısına müracaatta bulundular. Gayrimüslim sıvacıların müslüman ustaları aralarına sokmayıp müstakil işlemelerinden dolayı zarar gördüklerini, birlikte işleyerek kendilerinin ve ailelerinin geçimini sağlamayı istediklerini ifade ettiler. Fakat bu istekleri her defasında kanuna aykırı görülerek reddedildi. ${ }^{89}$

Sekiz buçuk yıl sonra, 1784 yılında İstanbul'da yaşanan büyük yangın ve sonrasında ortaya çıkan sıvacı açığı, bunu fırsat bilen gayrimüslim sıvacıların halka çektirdikleri sıkıntı ve eziyet, müslüman sıvacılara istedikleri fırsatı verdi. Mağduriyet ve şikâyetlerini içeren arzuhalleri üzerine görülen dava neticesinde, 1776 tarihli emrin iptaline muvaffak olarak yapılarda yeniden gayrimüslimlerle birlikte çalışma hakkı elde ettiler. İptalin gerekçesini oluşturan şikâyet konuları ise şunlardı:

1. Müslim sıvacıların eskiden beri zimmî sıvacılarla bir mahalde birlikte işledikleri ve yapı sahiplerine amele tedarikinde kolaylık gösterdikleri fakat zimmîlerin "Ehl-i İslâm ile bir binada işlemeyiz" diyerek çıkarttıkları fermanla kendilerini yapıdan uzaklaştırdıkları.

2. Zimmî sıvacıların, yapıda müslim bir sıvacı bulunursa yapıya gelmemeleri veya "Bu adam burada iken biz gelmeyiz" manasında cevap verdiklerinde, yapı sahibinin kendilerini yapıdan çıkartmak zorunda kaldığ ve bu durumun rızıklarının kesilmesine neden olduğu.

3. Zimmî kalfaların üstâdiye, götürü ve pazarlı usulüyle aldıkları yapıları "kendi cinslerinden" zimmî sıvacılara işletmeleri, onlar ile işlemelerinin yasak olduğuna istinaden kendilerine rağbet ve iltifat dahi etmemeleri.

Gayrimüslim sıvacıların, nizamlarının iptaline dair verilen fermana rağmen birlikte çalışmaktan imtina etmeleri üzerine müslüman sıvacılar sekiz ay sonra tekrar mahkemeye başvurdular. 1785 y1lında, İstanbul Kad1sının huzurunda Hassa Mimarbaşının marifetiyle iki tarafın kethüda ve söz sahibi ustalarının hazır bulunduğu davada müslüman sıvacılar, verilen

${ }^{89}$ Müslüman sıvacıların, Nisan 1776 tarihli emrin iptali için 7 Mayıs 1776, 19 Şubat 1777 ve 5 Nisan 1778 tarihlerinde İstanbul Kadılığına yaptıkları müracaatlar hakkında bkz. BOA, MAD.d, nr. 8947, s. 62-63; C.İKTS, nr. 1687. 
emir gereğince gayrimüslim sıvacılara kendileriyle birlikte çalışmaları hususunda tembihte bulunulmasını talep ettiler. Onlar da cevaplarında, çıkan fermanı kabul ettiklerini fakat müslüman sıvacıların kendilerini darp etmeleri, yaralamaları ve yevmiyelerini keserek zulmetmelerinden dolayı ferman çıkartıp bir binada birlikte işlemekten imtina ettiklerini ifade ettiler. Müslüman sıvacılar ise bu tür fiil ve hareketlerin kendilerinden çıktığını inkâr ederek, mesul olanların şiddetle cezalandırılmasına razı olduklarını belirttiler. Sonuçta, müslüman sıvacıların kethüda ve yiğitbaşılarına kendi içlerinden kaynaklı herhangi bir olumsuzluğun yaşanmaması, gayrimüslim sıvacılara da müslümanlarla birlikte bir binada işlemekten imtina etmemeleri hususunda tembihte bulunularak yeni bir emir çıkartıldı. ${ }^{90}$

Benzer bir emir, Bostancı Ocağı içerisindeki Hasbahçeye tâbi Sıvacı Ocağı mensuplarının talebi üzerine de verildi. Bu sıvacılar, kamu binaları dışında halka ait yapılarda, Boğaziçi ve Surdışındaki yalılarda şehir esnafıyla birlikte işleme hakkına sahiptiler. Gayrimüslim sıvacıların bu yapılarda kendileriyle birlikte işlemek istememeleri üzerine Hasbahçe sıvacıları da bunun önüne geçecek bir emir çıkartmaya muvaffak oldular. ${ }^{91}$

Müslim ve gayrimüslim sıvacılar arasındaki bu ilginç çekişme ertesi yıl da sürdü ve iki taraf 1786 yılında bir kez daha mahkemelik oldu. İstanbul Kadisı Mustafa Aşir Efendi'nin huzurunda görülen davada taraflar, önceki y1llarda kendilerine verilmiş olan belgeleri takdim ettiler. Gayrimüslim sıvacılar, ellerindeki 1776 tarihli ferman ve sonrasında müslüman sıvacıların itirazları üzerine 1776-1778 yılları arasında İstanbul Kadısı olanlar tarafından lehlerine verilen üç adet ilamın incelenmesi neticesinde haklı bulundular. 1784 yılında kaybettikleri avantajlı konumlarını tekrar kazanarak, müslüman sıvacılarla birlikte işlememe yönündeki 1776 tarihli fermanı

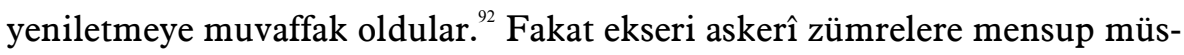
lüman sıvacılar bu kararı kabullenmek istemediler. Kırk elli kadar kadın ve erkek toplanıp kalabalık bir şekilde Divâna çıkarak, verilen ferman ve ni-

${ }^{90} 1776$ nizamının iptaline dair 15 Ekim 1784 tarihli ferman ve bu fermanın uygulanmasına dair 5 Haziran 1785'de verilen ikinci emir için bkz. BOA, MAD.d, nr. 8947, s. 63.

${ }^{91} 25$ Ağustos 1785 tarihli emir (BOA, C.BLD, nr. 6817; MAD.d, nr. 8947, s. 60), 16 Haziran 1793 tarihinde yenilendi (MAD.d, nr. 8947, s. 59/2).

${ }^{92} 11$ Aralık 1786 tarihli emir, cülus münasebetiyle 14 Eylül 1793 tarihinde yenilendi (BOA, MAD.d, nr. 8947, s. 62-63; C.İKTS, nr. 1687). 
zamın aleyhine edepsizce bağırıp çağırma cesaretinde bulundular. Bunun üzerine, nizamı korumak amacıyla çoğunluğu yeniçerilerden oluşan on sıvacının kalebentlik cezasına çarptırılarak Limni Kalesine gönderilmelerine karar verildi.

Amele sınıfı ve bu sınıf içerisinde yer alan sıvacıların nizamlarla belirlenmiş yevmiyelerine dair düzenli bilgilere, nakkaşlarda olduğu gibi 18 . yüzyıl başlarından itibaren rastlanmaktadır. Aşağıdaki tablo, sıvacı ustası ve çırakları için 1722-1750 yılları arasında yaz ayları için belirlenmiş yevmiye ücretlerini göstermektedir. ${ }^{94}$

\begin{tabular}{lccc}
\multicolumn{3}{c}{ Sıvacı Yevmiyeleri (6 } & Mayıs-9 Aralık) \\
\hline & $\mathbf{1 7 2 2}$ & $\mathbf{1 7 4 2}$ & $\mathbf{1 7 5 0}$ \\
\hline Sıvacı ustası & 40 akçe & 45 akçe & 55 akçe \\
Sıvacı şakirdi & & 30 & 40
\end{tabular}

Bu dönemde 40 akçeden 55 akçeye yükselen sıvacı ustası yevmiyesi, 18. yüzyılın ikinci yarısında da artışını sürdürdü. 1764 yılındaki düzenleme ile ücretler öncekilere nazaran daha ayrıntılı bir tasnife tabi tutuldu. Sivacı kârhanecisinin de yer aldığı listelerde sıvacı ustaları, kalemkâr ve sadekâr olarak ikiye ayrıldı. Ayrıca kış aylarındaki yevmiyeleri için ayrı bir kayda gerek duyulmayarak yaz aylarına göre beşer akçe indirime gidileceği belirtildi. ${ }^{95} 1776$ yılında, Mimarbaşı Hafız İbrahim'in kaleme aldığı arzuhalde ise özellikle sıvacı yevmiyelerindeki artıştan şikâyet ediliyor, İstanbul'da yapıların çokluğu nedeniyle sıvacı esnafının 50-60 para (150-180 akçe) yevmiye talep ettiği ve yapı sahiplerinin yüksek ücret vermeleri nedeniyle mirî yapılarda çalışmak istemeyerek firar ettikleri yazıyordu. ${ }^{96} 1764$ 'den itibaren aradan geçen on beş senede ücretlerde ciddi bir yükseliş yaşanmış-

\footnotetext{
${ }^{93}$ 13-22 Aralık 1786 tarihinde verilen bu ceza uygulanarak söz konusu on kişi zabitleri marifetiyle Limni'ye gönderildi. Fakat aradan üç ay geçtikten sonra sıvacı esnafı kethüdasının arzuhali üzerine 13 Mart 1787'de affedildiler (BOA, C.BLD, nr. 3301).

${ }^{94}$ BOA, MAD.d, nr. 8947, s. 90/1, 8 Kasim 1722; s. 78/2, 27 Şubat-8 Mart 1742; s. 101/1, 18-27 Şubat 1750.

${ }^{95}$ BOA, $M A D . d$, nr. 8947, s. 78, 24 Ekim 1764.

${ }^{96}$ BOA, C.BLD, nr. 5512; MAD.d, nr. 8947, s. 64, 11 Şubat 1776.
} 
t1. Nitekim 1779 yılına gelindiğinde ücretlerde güncelleme yapılması kaç1nılmaz bir zorunluluk haline geldi ve sıvacı esnafının yevmiyeleri yeniden belirlendi. Devletin belirlemiş olduğu ücret artış oranı bir önceki düzenlemeye göre $\% 50$ ilâ $\% 65$ arasında değişmekteydi.

\section{Sıvacı Yevmiyeleri}

\begin{tabular}{lcc}
\hline & $\mathbf{1 7 6 4}$ & $\mathbf{1 7 7 9}$ \\
\hline Sivacı kârhanecisi & 60 akçe & 90 akçe \\
Kalemkâri ustası & 55 & 90 \\
Sadekâri ustası & 50 & 75 \\
Şakirdleri & 35 & 55
\end{tabular}

Osmanlı tarihinde siyasî, sosyal ve ekonomik çalkantıların yoğun olarak yaşandığı Sultan II. Mahmud döneminin ilk yıllarında amele yevmiyelerine yapılan zamdan sıvacılar da payını aldı. 1811 ve 1813 tarihli bu ücret düzenlemelerinde daha keskin bir sınıflamanın oluştuğu görülmektedir. Ücretlerde yaz-kış ayırımının ortadan kalkması, akçe yerine paranın belirtilmesi, sıvacı kârhanecisi yerine sıvacı işçibaşısi tabirinin kullanılmaya başlanması, nakkaşlarda olduğu gibi kalemkâr ve sadekâr sıvacıların "usta" ve "bayağı" şeklinde ayrıma tâbi tutulması göze çarpan önemli ayrintılardır.

Sivacı Yevmiyeleri

\begin{tabular}{lcc}
\hline & $\mathbf{1 8 1 1}$ & $\mathbf{1 8 1 3}$ \\
\hline Sıvacı işçibaşısı & 100 para & 115 para \\
Üstad kalemkâr sıvacı & 95 & 110 \\
Bayağı kalemkâr sıvacı & 85 & 100 \\
A‘lâ sadekâr sıvacı & 80 & 95 \\
Bayağı sadekâr sıvacı & 70 & 80 \\
Sivacı sakirdi & 45 & 55
\end{tabular}

Müslüman sıvacılarla birlikte çalışmama haklarını 1786 yılından itibaren yeniden kazanan ve sahip oldukları sayı üstünlüğüyle mesleklerini te-

\footnotetext{
${ }^{97}$ BOA, MAD.d, nr. 8947, s. 40-41, 19 Nisan 1779.

${ }^{98}$ BOA, C.BLD, nr. 2755; MAD.d, nr. 8956, s. 3, 24 Eylül 1811.
} 
kellerinde tutmayı başaran gayrimüslim sıvacılar, bu imtiyazlı konumlarını 19 Ocak 1798 tarihli yeni Sıvacı esnafı nizamıyla tamamen kaybettiler. Ellerindeki fermanın iptal edilmesine temel oluşturan yasal dayanak, bazı esnaf gruplarındaki halka zarar veren tekellerin kaldırılmasına dair Sultan III. Selim'in 1789 tarihli hatt-1 hümayunuydu. Yeni düzenlemenin gerekçesini oluşturan hususlar ise şunlard1: ${ }^{99}$

1. İstanbul'daki mirî ve halka ait binalarda istihdam olunan sıvacı taifesinden, kalemkâr ustalar arasından sakallı olanların yanlarına ç1rak alıp matruşların (sakalsızların) çırak kullanmamaları.

2. Sakallı ustanın, kullandığ 1 çırağa 25 yaşını geçmedikçe izin vermemesi ve tek başına binalarda işlememesi.

3. Ehl-i İslam'dan olan sadekâr sıvacı ve kalemkârlar ile birlikte bir binada işlememeleri.

4. Sanatlarını kendilerine mahsus kıldıklarından ve bu sanatı tahsil etmiş birkaç ustadan ibaret olduklarından gün be gün yevmiyelerini artırmaları.

5. Mirî ve sair binalarda sadekâra verilen 2 kuruş ve kalemkâra verilen 2,5 kuruş yevmiyeye kanaat etmeyip 3 ve 3,5 kuruşa işlemek için mirî binalardan firar etmeleri.

6. Toplanma ve tedariklerinde dahi tam bir zorluk olduğundan, mirî binaların vaktinde bitirilememesine ve halka ait binaların da geri kalmasına neden olmaları.

Sıvacı esnafındaki tekelcilikten halkın ve devletin zarar gördüğünü ileri süren Şehremini Cavid Ahmed Bey, gerekçesiyle birlikte hazırlamış olduğu yeni nizamı bir takrirle Sadarete sundu. Nizam hakkında İstanbul Kadısının olumlu görüş bildirmesi ve son olarak da Padişahın hatt-1 hümâyunuyla onay vermesi üzerine yeni düzenleme yürürlüğe girdi. İçeriğini oluşturan maddeler şunlard1: ${ }^{100}$

1. Sıvacı esnafının sakallı ve kalemkâr ustalarının, yanlarına diledikleri kadar çırak alabilmeleri ve çıraklarının mahareti ortaya çıktı̆̆ın-

\footnotetext{
99 Sultan III. Selim'in hatt-1 hümâyunu üzerine 25 Temmuz 1789'da çıkan ferman ve 1798 tarihli yeni nizamın gerekçeleri hakkında bkz. BOA, C.IKTS, nr. 1687.

${ }^{100}$ BOA, Hatt-1 Hümâyun Tasnifi (HAT), 1410/57333; 222/12411; MAD.d, nr. 8947, s. 52/1, 16 Ocak 1798.
} 
da destur verdiklerinin de kendi başlarına işleyebilmesi ve yanlarına çırak alabilmesi.

2. Sakallı sıvacıbaşı ile sanatında mahir sakalsız bir sıvacı ustası loncaya dâhil olduğunda işlerini görmede beraber olmaları.

3. Kaleminde mahareti ortaya çıkan çırağa ustası destur vereceği zaman a lâ kalemkâr çırağa "üstâdiye" olarak 40 kuruş, evsat kalemkâr olana 30 kuruş, sadekâra ise 20 kuruş vermesi, başka yere bir akçe verilmemesi.

4. Mevcut sakallı ve sakalsız ustaların yanlarına ikişer üçer çırak alabilmesi.

5. Bir bina sahibi kendisine münasip bir sıvacı tedarik ettikten sonra ondan daha ucuz bir bedel ve yevmiye ile başkasını tedarik eder ise onu lonca edip azarlayarak yolsuz düşürmemeleri (işin yapılmasını engellememeleri), ustalar arasında hesabın görülmesi.

6. Mirî binalardan vesaireden firar etmemeleri.

7. Ehl-i İslâmdan olan sıvacılar ile zimmîlerin gerektiğinde bir binada muhtelitan (karışı) işleyebilmeleri. Müslim olanların esnaf olan zimmîleri sebepsiz yere rencide etmemesi, eden olursa cezaland1rılması. İçlerinden hoş olmayan hareketlere cesaret eden olur ise haber verilip, bu gibilerin esnaftan uzaklaştırılarak zabitleri marifetiyle cezalandirilması.

8. Bundan sonra, nizam altına alınacak konularda Hassa Mimarbaşı ile haberleşilmesi ve ne şekilde bir temşiyet (yürütme), nizam ve karar verilir ise arz olunması. Nizamın korunması hususuna Hassa Mimarbaşı olanların ihtimam ve dikkat göstermesi, hatt-1 hümâyuna aykırı hareket ettirmemesi. Aykırı hareket eden her kim olur ise olsun derhal tutuklanarak, diğerlerine ibret için başka memleketlere nefy (sürgün) edilmesi veyahut küreğe konulması.

1798 nizamının en önemli amacı, İstanbul'daki sıvacı sayısını artırarak yevmiye ücretlerindeki tırmanışı kontrol altında tutabilmekti. O yüzden de ustalara istedikleri kadar çırak çalıştırabilme hakkı verilmişti. Fakat ileriki yıllarda görüldü ki, yanlarına birkaç çırak almak nizamlarından iken sakallı ve kalemkâr sıvacı ustalarının ekseri kârlarını artırabilmek için çırak almaktan kaçınmakta, alanlar da çırağına destur verdikten sonra bir iki sene boş durup daha sonra isterse çırak alıp istemezse kendi başına çalışmaktaydı. Bu durumda sayıları artmak bir yana gün geçtikçe daha da azalan sıvacı- 
lar, yevmiye ücretlerini diledikleri gibi artırarak kendilerine müşteri seçiyorlardı. Yarım bırakıp gittikleri işlerle bina sahiplerini zarara sokmaları ve yevmiyelerini yedişer-sekizer kuruşa çıkarmaları üzerine 1812 yılında alınan bir kararla, İstanbul'da mevcut ne kadar sıvacı ustası ve çırağı varsa Mimarbaşı tarafından bir deftere kaydedildi. Ardından yapılan müzakerelerde, nizamda yer alan çırak yetiştirmeyle ilgili hususlar tekrarlanarak, ustaları tarafından destur verilen çırakların isimlerinin Mimarbaşı defterine geçirilmesine karar verildi. Şehremini İbrahim Rafet Efendi'nin takriri üzerine bu husus da nizama eklenerek, İstanbul Kadısına ve Hassa Mimarbaşıya hitaben nizamı pekiştiren yeni bir emir yazıldı. ${ }^{101}$

S o n u ç

Yap1 sanatkârları arasındaki tekelci uygulamalar 18. yüzyıl sonlarından itibaren halk ve devlet nazarında ciddi sıkıntılar doğurmaya başlamıştı. Bu sıkıntıların başında, Yeniçeri Ocağına mensup nakkaş, sıvacı ve sair amelenin, bir yerde bina inşasına başlandığını haber aldıklarında birer nişan tahtası getirerek inşaat mahalline asmaları geliyordu. Bu nişan, aynı zamanda mensup oldukları Yeniçeri ortasının işareti olup, bina sahibinin istediği gibi amele kullanamamasına ve çalışan amelenin yevmiyesinden de hisse yani bir nevi haraç almalarına vesile oluşturuyordu. ${ }^{102}$ Nişan tahtası kaldırıldığı veyahut istenilen meblağ verilmediği takdirde bir yeniçeri marifetiyle "balta asılarak" inşaat tatil edilirdi. Bir binaya balta asıldığında bina sahibi artık yapısına karışamaz, kimseyi de çalıştıramazdı. ${ }^{103}$ Özellikle Sultan II. Mahmud döneminde (1808-1839) yeniçeri kaynaklı bu tür sıkıntılar had safhaya ulaşmıştı. Şânî-zâde'nin verdiği bilgiye göre, iki kat gündelikle istedikleri kadar çalışan nakkaş, sıvacı, rendeci gibi amelelerden başka, ırgadbaşılık iddiasıyla elindeki küreğin sapı üzerine ortasının nişanını nakşettirmiş bir yeniçeri çıkagelir, haftalık verilen amele gündeliklerini bina sahibinden zorla alıp yarısını işçilere verir kalanını kendi alırdı.

${ }^{101}$ BOA, MAD.d, nr. 8957, s. 3, 2 Ekim 1812.

${ }^{102}$ Ahmed Lûtfî Efendi, Vak'anüvîs Ahmed Lûtfì Efendi Tarihi, haz. Ahmet Hezarfen, İstanbul 1999, I, s. 176-177.

${ }^{103}$ Osman Nuri Ergin, Mecelle-i Umûr-ı Belediyye, Yayın yönetmeni Cengiz Özdemir, İstanbul 1995, I, 608. Reşad Ekrem Koçu, "balta asma" tabirinin yeniçeri argosuna Sultan III. Selim devrinde girdiğini ve Ocağın kaldırılışına kadar kullanıldığını belirtmektedir ("Balta Asma”, İstanbul Ansiklopedisi, İstanbul 1980, IV, s. 2067. 
Ameleyi boğaz tokluğuna çalıştırmayı âdet edinen 1rgadbaşılar, bina işlerine başkasını karıştırmayıp tuğla, kiremit, kereste, çivi gibi yapı malzemelerini de mutlaka kendi marifetleriyle diledikleri yerden alıp verirlerdi. ${ }^{104}$

İcra ettikleri sanatlarını tekellerinde tutmaya çalışan nakkaşlar da İstanbul'da inşa edilen yapılarda istedikleri gibi fiyat vererek maliyetin yükselmesine, dolayısıyla devletin ve halkın zarar görmesine neden oluyorlardı. Ayrıca, kendileri dışında bu sanatı icraya muktedir başka kimselerin çalıştırılmasını da engelliyorlardı. Aynı şey gayrimüslim sıvacılar için de geçerliydi. Onlar da tekellerine aldıkları mesleklerine yabancı birinin dâhil olmasına ve müslümanlarla birlikte çalışmaya kesinlikle karşıydılar.

1826 yılında Yeniçeri Ocağının kaldırılması, Ocağa bağlı esnaf gruplarını etkisiz ve işlevsiz hale getirdi. Bundan istifade ile devlet, 1827 yılında önemli bir karara imza atarak nakkaş ve sıvacı esnafının meslekî tekellerini tamamen kaldırdı. Sultan III. Selim'in bazı esnaf gruplarındaki tekelciliğe son veren 1789 tarihli hatt-1 hümâyununa aykırı olduğu gerekçesiyle, bundan sonra sıvacı esnafı içerisinde nakkaşlık sanatını bilenlerin nakkaşlık, nakkaş esnafı içerisinde sıvacılık sanatını bilenlerin sıvacılık yapabilmelerine, tekelciliği ortadan kaldırabilmek için birbirlerinin işkolunda çalışabilmelerine karar verildi. ${ }^{105}$

Nakkaş ve sıvacıların, belki de pratikte geçerliliğini çoktan kaybetmiş tekelci anlayışlarına resmen ve kesin bir şekilde son veren bu kararın üzerinden on yıl geçtikten sonra, 1838 yılının Ocak ayında İstanbul'da yeni bir sayım yapıldı. Oldukça teferruatlı olan bu sayım, nakkaş ve sıvacı esnafiyla ilgili çok kıymetli bilgiler içermektedir. Sanatkârların memleketleri, isimleri, ayırıcı fiziksel özellikleri ve İstanbul'da kaldıkları mekânlar ayrıntılarıyla kaydedilmiştir. ${ }^{106}$ Buna göre;

Nakkaşların sayısı 520 kişi olup tamamı müslümandır. Bunların 360'1 Kayserili (\%69), 109'u İstanbullu (\%21), 11'i de Taşköprülü (\%2)'dür. Geriye kalanlar ikişer üçer kişiyle Sinop, Nevşehir, Safranbolu, Çorlu, Kasta-

\footnotetext{
104 Şânî-zâde Mehmed 'Atâ'ullah Efendi, Şânî-zâde Târîhi [Osmanlı tarihi (12231237/1808-1821)], haz. Ziya Y1lmazer, İstanbul 2008, II, s. 960.

${ }^{105}$ Istanbul Kadılı̆̆ 154 Nolu Ferman Defteri, vr. 47a, 23 Şubat 1827.

${ }^{106}$ BOA, Nüfus Defteri (NFS.d), nr. 23, s. 278-323, Ocak 1838.
} 
monu, Çankırı gibi farklı memleketlere mensuptur. Bu sayının yarıya yakın kısmı (222 kişi) İstanbul'daki hanlarda ikamet etmektedir. Bu hanlardan Fazlı Paşa Hanı 72 kişiyle başı çekmektedir. Diğerleri sırasıyla Nakib Han (53), Nakkaşbaşı Hanı (44), Mezberelik Han (40) ve Şekerci Han (13)'dır. Bunlardan Mezberelik ve Şekerci Han, Sultan Mehmed (Fatih)'de bulunmaktadır. Ayrıca Fatih Çukurçeşme'deki Molla Kestel Mahallesi de 43 kişiyle nakkaşların en yoğun olduğu mahalledir.

Sıvacıların sayısı ise 257'si müslüman (\%44), 325'i gayrimüslim (\%56) olmak üzere 582 kişidir. Müslüman sıvacıların 197'si Kayserili (\%77), 11’i İstanbullu (\%4), 9'u Şileli (\%3,5), 6's1 Kastamonulu (\%2)'dur. 257 kişinin 150'si hanlarda kalmaktadır. En başta 101 kişi ile Nakib Han gelmektedir. Diğerleri sırasıyla Nakkaşbaşı Hanı (26), Mezberelik Han (9), Emirler Hanı (8) ve Tahta Han (2)'dır. Emirler Hanı ile Tahta Han da Fatih'te bulunmaktadır. Molla Kestel Mahallesi (8) ile Tophane'deki Cihangir Mahallesi (6), müslüman sıvacıların en kalabalık oldukları yerlerdir.

325 kişi ile çoğunluğu Ermenilerden oluşan gayrimüslim sıvacıların 237'si Kayserili (\%73), 53’ü İstanbullu (\%16), 24'ü Develili (\%7)'dir. Hanlarda kalanların sayısı 125'tir. İlk sırayı 51 kişi ile Vezir Hanı almakta olup ikinci Şekerci Han (41), üçüncü Fazlı Paşa Hanı (19), dördüncü Yeni Han (7)'dır. Diğerleri ikişer-üçer kişiyle Emirler Hanı, Meyhaneli Han, Çadırcı Han, Sakalı Han, Taş Han, Deve Hanı, Buzcu Hanı, Yağlıçıı Han, Hasan Paşa Hanı, Süleyman Paşa Hanı ve Alçı Han'dır. Gayrimüslim sıvacıların yoğun olarak bulundukları semtler ise Çarşamba (33), Langa (16), Kumkap1 (6), Yenikapı (5), Samatya (3), Balat (3) olup Üsküdar'daki Yeni Mahalle (20) ile Selâmi Ali Mahallesi (9) de Anadolu yakasında kalabalık bulundukları yerlerdir.

Yapılan sayım, nakkaş ve sıvacılar arasında Kayserililerin \%72 gibi bariz bir çoğunluğa sahip olduğunu, İstanbulluların ise \%16'da kaldığını göstermektedir. Ağırlıklı olarak Fatih ve civarındaki mahallerde ikamet eden esnaf mensuplarının önemli bir kısmının şehirdeki hanlarda kaldığı ve bu hanların amele sınıf için ikamet mahalli olmanın yanı sıra işyeri özelliği de taşıdığı anlaşılmaktadır. Farklı hanlarda yoğunlaşan nakkaş ve sıvacıların bulundukları mekânların başında Nakib Han, Fazlı Paşa Hanı, Nakkaşbaşı Hanı, Şekerci Han, Vezir Hanı ve Mezberelik Han gelmektedir. İsimlerinin ardından verilen yüz odaklı fiziksel tasvirler ise kara sakallı, kır sakallı, 
kırca sakallı, kumru sakallı, kara kır sakallı, sarı sakallı, sarı bıyıklı, ter bıyıklı, terce biyıklı, kumru biyıklı, kır bıyıklı, kırca bıyıklı, kara biyıklı, kara kumru bıyıklı şeklindedir. Müslüman nakkaş ve sıvacılar arasında sakallı olanlara rastlandığı halde gayrimüslim sıvacıların tamamının bıyıklı olduğu görülmektedir.

Sonuç olarak, Osmanlılarda "nakkaş" unvanının kullanımı, nakkaşlığın temelde saraydan neşet etmiş bir sanat oluşu ve bu sanatı icra edenlerin Ehl-i hiref ve Hassa nakkaşlara olan bağlılıkları dolayısıyla sadece müslümanlara mahsustu. O yüzden gayrimüslimlerin İstanbul içinde ya da dişında bu unvanla nakkaşlık yapmasına kanun ve nizamlarına aykırı olduğu gerekçesiyle izin verilmezdi. ${ }^{107} 1838$ sayımında, nakkaşlar arasında tek bir gayrimüslimin bulunmayışının nedeni de buydu. Sıvacılara dair bilgiler ise sıva üstü boyalı nakış sanatında nakkaşların sektörde yalnız olmadığını ortaya koymaktadır. Nitekim yapılan ücret düzenlemelerinde 1764 yılından itibaren kalemkâr ve sadekâr sıvacılara yer verilmesi, 1776 tarihli sıvacı nizamında yumurtalı ve yağlı boyalı nakış yapan sıvacılardan bahsedilmesi ve 1826 yılında sıvacılara verilen yağlı boya sürme izni, bu sanatın icrasında 18. yüzyılın ikinci yarısından itibaren sıvacıların etkinliğinin arttığını göstermektedir.

${ }^{107}$ Edirne, Bursa ve İzmir kadılarına, bu şehirlerde kanun ve nizama aykırı nakkaşlık yapmaya başlayan Yahudi ve Hristiyanlara engel olunması için 14 Nisan 1764 tarihinde yazılan emir, cülus münasebetiyle 23 Şubat 1776 ve 17 Mart 1790 tarihlerinde yenilendi (BOA, MAD.d, nr. 8947, s. 90). 


\author{
“Construction Craftsmen of Istanbul: \\ Wall-Decorators and Plasterers (1700-1838)"
}

\title{
Abstract
}

Except for Ottoman Palace craftsmen (hassa) so called "ehl-i hiref" who had special status in the palace and workshop owner decorators, there was another group of decorators who had been populated more than others. This group of workers (amele) class as decorators used to make over-plaster decorations of state, religious and civil buildings. These decorators, under the umbrella of ehl-i hiref and subjected to Enderun Hazinedarbasstsi (head-treasurer), had special statues and regulations related to mastery and apprenticeship. Plasterers as one of craftsmen groups were parts of workers' (amele) class. Most of them were non-muslims. Minority muslim plasterers were military staff as well. According to regulations dated 1776, muslim and non-muslim plasterers were banned to work together. Wall-decorators and plasterers created monopoly in their work and did not interfere each other. The abolition of Janissary corps in 1826 artisan groups were also passivated. Using this opportunity Ottoman administration cancelled wall-decorators and plasterers' professional monopolies. This article aims to analyze wall-decorators and plasterers who fulfilled and related each other closely, their relations with the palace, their origin, wages, numbers and regulations.

\section{Keywords}

Wall-decorator, plasterer, kalemkâr, sadekâr, repairer, Palace gardener, İstanbul, construction, building, craftsman, decoration, ornaments. 